Culture, Personality and Education

МәАәният, шәхес һәм мәгарифр

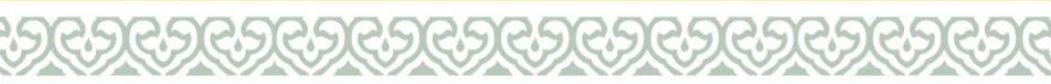

Культура, Аичность и образование

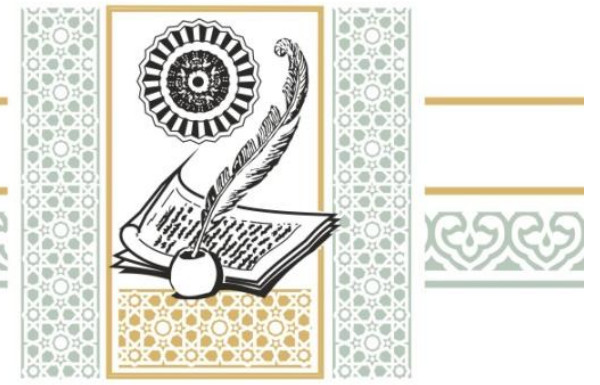

DOI: $10.26907 / 2311-2042-2021-17-2-119-140$

\title{
NAKIE ISANBET ON CHICHAN ART ${ }^{1}$
}

\author{
Mileusha Mukhametzyanovna Khabutdinova, \\ Kazan Federal University, \\ 18 Kremlyovskaya Str., Kazan, 420008, Russian Federation, \\ mileuscha@mail.ru.
}

Fanuz Afgalovich Khabibullin,

"Кyzyl taң" editorial office, 18 50-letiya Oktyabrya Str., Ufa, 450001, Russian Federation, kiziltan90@mail.ru.

\begin{abstract}
The article systematizes the contribution of Nakie Isanbet, an encyclopaedist, folklorist, and classic author of Tatar literature, to the study of chichan (bardic) traditions in Turkic culture. The material for this research is based on the scholar's theoretical works devoted to the study of the Turkic peoples' folklore, his studies of oral folk art systematized in the collections of folklore expeditions, his works that include the image of chichans (bards). The method of study in our article is determined by the features of the analyzed text (cultural and historical, semiotic and cultural, comparative, etc.). $\mathrm{N}$. Isanbet's theoretical works on folklore prove that he attempted to form a complete understanding of chichan (bardic) poetry and to perpetuate their images in his literary work. In the 1920s, the experiments of the scientist in collaboration with F. Davletshin resulted in compiling a collection of his works. The analysis of modern works on the study of Bardic (chichan or sasan) phenomenon in the Turkic environment shows the following: there is certain scepticism among modern researchers towards Nakie Isanbet's contribution to the study of this topic.
\end{abstract}

Key words: Nakie Isanbet, folklore, Turkic peoples, Tatars, bard, chichan.

\section{Introduction}

The debates over the issue of Bards and their tradition as a peculiar phenomenon in traditional folklore finally came to an end in the second half of the $19^{\text {th }}$ century. That was the time of achieve-

\footnotetext{
${ }^{1}$ chichan - a bard in Turkic culture (chachan, sasan, aqyn).
}

ments made by the School of Russian Folklore, founded by V. Radlov, P. Rybnikov, A. Gilferding and their disciples. In Soviet times, there was an increasing interest in this phenomenon in the national republics, where the centers of folk epic poetry still existed. At that time, according to the folklorist B. Putilov, the traditions of the oral epic were preserved in various forms in Central Asia, 
Siberia, the Far North, Transcaucasia and the North Caucasus, Moldova, Ukraine, the Volga region, the Russian North and Karelia [Putilov].

Researchers have always paid considerable attention to the phenomenon of bards and minstrels in Turkic culture. Turkologists have systematized the thesis of words that describe the art of aqyns, chichans, bards, abyzs, and zhriraus ([Radlov, pp. 120-121], [Kashgaryi], [Isənbət, pp. 333-334], [Sageeva] et al.). Both folklorists ([Zhirmunskii], [Bakirov], [Бурангулов], [Vəliullina], [Omineva], [Soltangərəeva] et al.) and musicologists [Gaziev] have made their contribution to the study of the art of improvising singers and bards.

The main purpose of our research is to evaluate the contribution of the encyclopaedist Nakie Isanbet to the study of this scientific subject.

\section{Materials and methods of research}

Our research is based on academic articles, dictionaries, collections of folklore research, and Nakie Isanbet's literary works. The research methods, we used, include cultural and historic, semiotic and cultural, comparative methods, etc.; their choice was determined by the peculiarities of the text to be analyzed.

\section{Discussion}

We consider that modern researchers underestimate the contribution made by Nakie Isanbet to the study of chichans - the phenomenon of Turkic folk poets-improvisers. Nakie Isanbet was born in the village Maloyaz in the Republic of Bashkortostan. When he was a madrasah student, at the age of 10 , inspired by the example of G. Tukay, he began to collect samples of the oral tradition. Baki Urmanche believed that the formation of the outstanding folklorist was positively influenced by his studies at the "Muhammadiyah" madrasah and his immediate environment: "At that time, Khuja Badigyi, one of the teachers of the "Muhammadiyah", a charming and a very sympathetic person, began to collect folk literature. $\mathrm{He}$ tried to instill compassion for folk literature in his students. If the great scientist and educator Qayum Nasiyri was an exception as a researcher of folk literature, then Khuja Badigyi, Gali Rahim, Gaziz Gubaidullin, who also studied in the "Muhammadiyah", were greatly interested in folklore" [Urmache, p. 132].

$\mathrm{N}$. Isanbet continued collecting folklore while working as a school teacher. In his diary, "Ber dərvishneң iul dəftrpe" ["One Dervish's Travel Book"], N. Isanbet describes his encounter with the improvisational poet Faizullah, quray players Husnullah and Gabdelgaziz in the village Sait (Bashkortostan), not far from Irendik, during which he recorded 50 ancient songs and tonal patterns [Isənbət, Ber dərvishneң iul dəftrpe, p. 50].

It is widely known that $\mathrm{N}$. Isanbet met chichan Farrakh Davletshin, known as Blind Farrah, in person. The scholar exerted great influence on this bard's fate. As a result of his three months' research, he decided to publish the improvisational poet's collection of works [SYz tabuchy sukyr Fərrəkh әңgəmələre]. In the introductory article, the folklorist wrote about a chichan who became disabled after an accident: "In the lowest part of the village, near the ravine, there lives the country's cripple in a house without fences. He is not a beggar, he is crippled. He spends his winters in that house playing a broken garmon or his homemade violin, telling fairy tales and bywords, singing bayts and songs, and burning birch firewood from the cemetery. He attends aulak oi gatherings, visits events, sometimes he goes to the village club. With the onset of spring, when the ground gets dryer, he goes to Sabantuy and gatherings (Jien). He is there to meet the needs of many people and please their souls. The mourners ask him to tell bayts, the youth want to hear fairytales, funny stories, songs and proverbs. He does not leave these gatherings empty-handed because of his skills, he even earns a few coins there. Travelling from land to land, he does not miss what he cannot see and cannot hear.

Great masters of language who collect folk wisdom, folk poets with exquisite speech skills are found among this type of the disabled. The broad masses of people satisfy their souls' needs by listening to these poets with their melodic, passionate and rich natures, with the music of their lives in their songs. Compared to the majority of educated poets, whose languages, souls and lives are alienated from the broad masses of the people, these "ignorant" poets are both closer and more necessary to the people. Farrakh is also a master of words and one of the folk poets".

"Who is Farrakh? At first, he was a shepherd, and as he grew up, he became a factory worker. Not long after, he got blind and became a countryman again". [SYz tabuchy sukyr Fərrəh әңgəmələre, p. 2].

For the blind singer, his encounter with $\mathrm{N}$. Isanbet was truly a gift of destiny. "SYz tabuchy sukyr Fərrəkh əңgəmələre" initiated a literary biography of the improvisational poet. Because of the folklorist's moving from Ufa to Kazan, Farrakh 
Davletshin's second book was published 10 years later [Ordenly khalyk iyrsyhy Fərrəkh iyrz̧ary həm bəiettəre].

When compiling a collection of F. Davletshin's works, N. Isanbet strived to convey the unique style of his improvisational work to the reader: "Мин китап сүзе сөйләмим. / Сөйләр идем белмимен / Китап сөйләргә чакырсагыз да / Килмимен!" (literal translation: "I do not tell stories from books / I would but I do not know any / If you invite me to retell a book / I'll refuse to come!"). [Syz tabuchy sukyr Fərrəkh әңgəmələre, p. 7].

The autobiographical myth of Blind Farrakh coincides with the reality of his life path ([Vorontsov], [Khəbibullin, Alsalar da kyzemne...], [Khəbibullin, Fərrəkh Dəylətshin ezləre...], [Khəbibullin, Fərrəkh Dəylətshin], [Iarmi Səete], [Iarullin]). According to the "personal leaflet", filled out on February 8-10, 1939, and his autobiography, Farrakh Davletshin was born into a poor peasant family on January 18 (January 31 in the new style), 1887, in the village of Staroe Urtaevo, the Birsky district in the Ufa province (now the Dyurtyulinsky district of Bashkortostan). By the time when Farrakh was born, his father was 60 years old and his mother was 18. Fate was cruel towards Farrakh Davletshin: his father passed away when he turned three years old; at the age of five, his mother left him and married another man. The boy was left in the care of his brother from a different mother. From the age of five or six, he lived at his own expense: earning by babysitting and shepherding.

From an early age, Farrah liked to listen to singers, storytellers with their bayts and fairytales and to retell what he had heard to the people. His communication with the famous master of word, the poet of fairy-tales Shavali, had a great impact on Farrakh when he listened to his works while working for the landlord Koshcheev. He used to retell Shavali's stories and, following his steps, began to compose his own fairytales.

At the age of 18, Farrakh Davletshin found a job at the Asha-Balashov felling plant in the Chelyabinsk region. Then he was as a laborer for the Yekaterinburg railway. From 1908-1910, he worked for Koshcheev and Limbursky, the landowners of the Birsk Uezd. He was also a laborer at the Siberian Railway. A year later, he moved to the Bogoslovsky plant, located near Yekaterinburg, he did timber rafting in summer and cut wood in winter. Then, he was a miner at the GornoBlagodatsky mine for a year. From 1912 to 1916, he worked at the "Belyi Kliuch" paper mill, where a steam pipe exploded, blowing hot steam at him, and left him blind.

Thus, Farrakh Davletshin had to return to his native village. At that time, Farrakh had no land to sow, no bread to eat and no house to live in. He composed songs and verses and told them in markets, assemblies, in "aulak oy"s, he sang about the needs of his people and laughed bitterly at those who oppressed the people and their rights. Neither the starostas nor the mullahs, not even the police officers appointed by the authorities could stop him. When he was chased away from Sabantuys or market squares, he gathered the youth in his dark bath house and told them his bayts there. That was how he fed his family.

Along with the fact that "Iugalgan tai əkiiate" ("The Lost Foal's Tale") (1909) is one of the most beautiful examples of the improvisational poet work, the story behind its creation shows us the author's high reputation in society.

The story behind it is as follows: the Kyrgyz man, whom he worked for, lost a herd of horses. The rich man was so upset about it that being aware of Farrakh's skills, ordered him to compose a bayt about it, promising to give him one of the horses in case they are found. Farrakh composed a bayt, told it to the people around him, thus attracting many people to the search of the rich man's horses. After a while, the horses were found but the rich man refused to fulfil his promise. Then, fearing the punishment of Allah, he gave Farrakh a horse. They say that this horse was the only animal the poet had ever owned before the revolution.

"In this work, Farrakh shows that he is a master of words, he creates a unique form of poetry, and this form exists in his poetry to this day as the "Farrakh form" and it keeps improving", - said Abubakir Usmanov, a historian, folklorist, writer, Honored Scientist of Bashkortostan, director of the Bashkir Scientific Research Center of History, Language and Literature from 1937 to 1951 [Iyrз̧ar həm bəyetter, p. 5-13 ].

F. Davletshin considered "Nuriia bəete" to be one of his most famous works. "This bayt made me famous among people. I started to receive invitations from other districts specifically to read bayts there", wrote the chichan in his autobiography [Davletshin]. "One of chichan Farrakh's most notable works, "Nuriia bəete" ("The Bayt about Nuriya"), is based on a true story. However, its generalized meaning is much greater. Sania, one of the characters in the bayt puts Nuria's lost ring above human life. The worship of material things 
and wealth takes away her human qualities forever. As a result, Nuria becomes a victim of Sania's cruelty. "Nuriia bəete" is a tragedy, but this tragedy is one of the types that encourages the reader to be a decent human being," writes the scientist, philologist and literary critic Kim Ahmetzyanov [Səsən tauyshy, 3-8 p. ].

Farrakh has another composition depicting his visit to Kazan in 1930. It is called "ForrakhnyH Kazanga bargan iullary" ["Farrakh's Roads to Kazan"]. The chichan took his poems and set off without a penny in his pocket. The blind man went to Kazan alone, on foot. Feeding himself by telling bayts in public, spending nights in village houses, passing Dyurtyuli and Verkhneyarkeyevo, he finally reached Menzelinsk. He found a companion at the city market. Together they arrived at Naberezhnye Chelny. They got hired by someone to cut wood for them. That person cheated them and did not pay what he owed them. Then they dug up potatoes in his garden and ate them. After passing Yelabuga and Mamadysh, they got to Kazan, where they parted ways. Farrakh Davletshin found the apartment of the prominent Tatar writer Nakie Isanbet.

He wrote (literal translation):

"Мамадышны үтеп киткәч, ерак түгел Казан $\partial а$,

Казаннарга барып кергәч, йөримен базарларда.

Ипташем китте уң белан, үзем киттем сул белән,

Исәнбәтне эзләп таптым, трамвайский юл белән”

("After passing Mamadysh, Kazan is not far away/ kets/

When I got to Kazan, I walked around its mar-

My companion went to the right, and I went to the left/

I found Isanbet walking along tramway tracks")

Nakie Isanbet welcomed him and spoke sincerely to him. Farrakh stayed the night at his place and went to the Press House the next morning, where he did not succeed in realizing his desire to see his works in print: they took his manuscripts but did not publish them as a book.

"The literary works of such writers as Farrakh Davletshin, Sait Ismagilov, and Mukhametsha Burangulov have aroused debates as to whether they belong to written literature or to folklore. This is a significant literary problem. There is only one thing to say here - none of these works is a poem in its modern sense, and the name "People's chichan", given by the administration of the Republic, precisely characterizes their poetic activity," argues Kim Ahmetzyanov. "Farrakh Davletshin's literary works are mainly characterized by the form of a bayt. It is worth mentioning that, despite the diversity in terms of their style and stanzas, most of the works of these three chichans are close to poetry in this genre. Keeping in mind that before the revolution, folk art did not know such a genre as poetry, one can better understand the innovations in chichans' literary activity.

There are also many new poetic features in Farrakh Davletshin's literary work. The chichan had notable merit in the enrichment and diversity of Bashkir folklore genres. In fact, he combined the genre of the bayt, depicting grief, with the motifs that are reminiscent of odes. His works, such as "Чкалов бәете" ("Chkalov's Bayt"), "Галия кыз бәете"(Galiya's Bayt), "Ватан сугышы бәете" (Bayt about the Patriotic War), "Стаханов турында" ("About Stakhanov"), create the portrait of outstanding people through the poetics of bayts. In such works as “Талип” (“Talib"), “Янгир абзый” ("Uncle Yangir"), "Габдрахман" ("Gabdrakhman"), the chichan shows his ability to depict complex social phenomena not through common words, but through the fate of individual people. $\mathrm{He}$ also tries his hand at such genres as parody and epigraph, which are unique only to written literature. F. Davletshin has great examples of humour and satire in his poems "Ялкау" ("The Lazy One"), "Чалмалылар" (The Turbans), "Гыймай бай” ("Gimay Bai”), “Алты ялкау бәете” (Six Lazy One's Bayt).

In many bayts and poems, Farrakh used different numbers of syllables in the lines of the same stanza. By doing this, he could increase the emphasis on individual words and sentences" [Səsən tauyshy, 3-8 p. ].

Farrakh Davletshin's songs and bayts were compiled into books (1938 - “Орденлы халык йырсыһы Фәррах йырзары һәм бәйеттәре” (Йырз̧ар һәм бәйеттер), 1947 - “Чәчәннең киңәшләре" (Сәсәндең кәңәштәре), 1967 “Чәчән тавышы” (Сәсән тауышы)) and distributed in large circulations, some of his works were translated into Russian and published in national journals and almanacks. His literary activity is studied in schools and pedagogical institutes of Bashkortostan.

Given the social, political and artistic significance of the chichan's creative work, on April 14, 1944 , by the decree of the Presidium of the Su- 
preme Soviet of the Bashkir ASSR, Farrakh Davletshin was awarded the honorary title of "People's Chichan of the Bashkir ASSR" [Ukaz Prezidiuma Verkhovnogo Soveta Bashkirskoi ASSR].

Unfortunately, M. Vorontsov does not mention Nakie Isanbet's name in his article, assessing the scientist's activity as a "local man of letters" who created songs for Blind Farrakh. [Vorontsov, p. 48]. The reason for this "loss of memory" can be found in the biography of Nakie Isanbet. M. Vorontsov might have forgotten to mention the name of the Tatar scholar because the latter was a "жсидегәнче" (a person who shared counterrevolutionary and nationalistic political views). A. Kutuy, N. Isanbet, T. Chenakai, and G. Minsky were arrested on February 7, 1931, in Kazan. They were accused of forming a counter-revolutionary organization. The 8-month investigation did not yield any results. G. Minsky and Nakie Isanbet were released on April 15 ("on their own recognizance"). A. Kutuy and T. Chenakai were released by the prosecutor's office on September 16 due to lack of evidence. There may be another reason for this "memory loss". Nakie Isanbet moved from Ufa to Kazan in 1930. The Bashkir scholar "took offense" at the Tatar folklorist: rumor had it that they thought that $\mathrm{N}$. Isanbet had donated his folklore materials, collected in Bashkortostan, to the Tatars. The writer's archive contains a certificate that N. Isanbet was an employee of the Language and Folklore Detachment of the Bashkir Expedition of the USSR Academy of Sciences in 1928.

In one of his radio interviews, the Tatar scholar defined the study of oral folk art in his biography as follows: "Along with writing various poems, dramas and other literary works for fifty years, I have never stopped collecting and studying folk art. I still cannot fully publish this folklore. But I have collected a lot of works.

I love folk oral tradition first and foremost, and I value it very much. Moreover, this knowledge always helps me in my writing career" [Isənbət. Minem iazuchy buluym həm khalyk iжаtyn eirənyem].

Nakie Isanbet proved that ancient Tatar poets and rulers were called chachan/chichans and that they played a major role in the life of their tribes, citing many facts from ancient dastans, proverbs and historical sources. In his work "Məkal'lərebez turynda" ("On Our Proverbs"), the scholar explained the meaning of the word chichan: "Not only the people who used to be called chichans are now extinct, but even the word itself has fallen out of use and is now only found in folk art. In the 1912 edition of his collection of proverbs, Kh. Badig described the word chichan as "neat, smart, nifty", but only in the 1926 edition of the book clarified its meaning as "a master of words".

In each of the two editions of the book, the word is spelt as "чечән" (chechan). This word is known to mean "eloquent" among people. There is a saying "Ул бик телгә чичән кеше" ("Hе is a very eloquent man"). The form "чәчән" is also used in some dialects. The Kazakh people have the word "шешен" (/sheshen/), the Bashkir people say "сәсән" (/sasan/). The latter even used to have an illustrated literary magazine with the same title, and several folk poets, who could freely improvise songs, were given the title of sasans. This fact is even more significant for our research. It shows that the word chichan means both the ability to speak eloquently, and a person, an improvisational poet who recites a poem with inspiration, without writing it down on paper. This is also confirmed by history. The word "chichan" used to mean both a master of words and an improvisational poet, a bard. This interpretation nominates a person who combines both professions, an ancient folk poet" [Tатаr khalyk məkal'ləre, pp. $41-42$ ].

After studying proverbs, fixed expressions and dastans, which are widely used by the people, $\mathrm{N}$. Isanbet determined the role of the chichans in society since ancient times and proved that bards had an irreplaceable reputation among the people: "It is clear from the Tatar proverbs that we have a large number of respected people called chichans: $Б a$ тыр яуда беленер, чичдн дауда беленер (A hero is known in the time of misfortune, and a bard is known in in the time of conflict). This proverb means that while heroes are known for their ability to eliminate hostilities on our border, the language skills of bards are known for resolving domestic disputes (conflicts). Чичәннец теле уртак, чибәрнең кульы уртак (A bard's language is common and a beauty's hand is common). In this case, the proverb means that a bard's word has sense and wisdom, it has general significance which is shared by the people. Chichan's skills are comparable to those of a skilled man at work. Moreover, judging by ancient folk dastans, chichans were profilers too. For example, in tribal and feudal life, it was necessary to verify the identity of a person. At that time, it was not easy to confirm. This specialization was of particular importance since the legal status and rights of people around the government depended on their background and lineage. This work, which required such abilities and skills, was 
called "сынчылык" (profiling). (This word should not be confused with modern word sculpture.) Profilers were supposed to describe a person's offspring, origins, his/her personal qualities, and future fate by quickly analyzing his/her appearance and behavior and asking a few indirect questions. It is very important for us that such a mysterious and wise thing as prophecy was performed by chichans. So, for example, it is clear from the dastans that the elder Khan, in order to unravel the identity of one of his new ambassadors, summoned a chichan, an elderly singer who lived somewhere among the people. It is quite impressive that the old man, about two hundred years old (that is, a person who had seen a lot, had put many people to test, and had huge life experience), who after numerous requests and prays, arrived in a gilded cart with cotton cushions, sat proudly in the front row at the Majlis (event), and the Great Khan himself knelt before him as if he were his footman and treated him to honey. He was completely at ease and felt quite independent communicating with the elder Khan. After reluctantly accepting his request, the bard began to test the ambassador covertly, as mentioned above, by asking him to do a small favor and answer one or two indirect questions. After watching his face and gestures, he took his dumbra and began to reveal his identity by telling the said ambassador's past and future. Interestingly, his words were arranged like half a verse and half a song, consisting of columns rich in proverbs and poetic images.

We have seen that the origins of proverbs are, on the one hand, related to ancient testing, experimentation, and even fortune-telling. Here, we see that this particular feature was put to the test by a chichan, that is, the ancients believed that a proverb was born by a test and assumed that it was possible to create a person's profile through the ability to put proverbs in a certain order adding a few figurative words to them. Thus, we see that in ancient times, proverbs and the ability to create them were highly valued; the proverb was considered to have a secret, some mysterious, wise power, and the person who had such skills could act as a great prophet. In this respect, the chichan was close to the ancient Greek oracle, priest of the Egyptians, sheikh/kahin of the Arabs, baguchy, baqsi, Bakhshi, kuraza, shaman, and synchi of Turkic people. So, we believe that when the life of the ancient tribes became more complicated, the elders and shamans were no longer able to accumulate a wealth of language, experience and wisdom, their people's folklore, and these ideological and artistic responsibilities were eventually transferred to poets-chichans who were real masters of this business.

Of course, the ancients treated such bards and chichans with respect, believing them to have the magical power of experience and wisdom, so the khans pronounced their names in awe and tried to win chichans' hearts to extend their power through them and boost their popularity among the people. Nevertheless, as we know from history and the examples given above, chichans, who were considered to be national poets and leaders, highly valued their profession; still, there were times when they initiated the movements that led to popular uprisings. In this case, their linguistic and creative power became a real force, posing a serious threat to the rulers. It is known, for example, that Jamukai Chichan was at the forefront of the Naiman uprising, rebelling for thirty years, fighting with his sword, made of words, against Genghis Khan's sword.

As we know from the history of China, people called sasanygs (chichan, chachan, sasan) were found among representatives of Turkic tribes from ancient times, and they left a noticeable trace in the socio-political movements of the people. Thus, it is quite impossible to determine whether the word chachan/chichan is derived from " $\mathrm{YZ}$ avyzynnan shigyr'-khikmət chəchə belyche" (who knows how to sow poetry and wisdom from his mouth) or "məs'ələ chishə belyche khakim" (a ruler who can solve a problem). However, the fact that this word occurs in the languages of all Turkic peoples and is widespread from China to our present lands, shows that in the times of ancient tribalism and patriarchy, such a genre was prevalent in all forms of art" [Taтar khalyk məkal'ləre, pp. 41 - 42].

In his article, N. Isanbet describes chichans' creative activities in great detail: "How does a chichan, as an improviser, compose? It is important to know. For us, he is indeed an ancient poet, he has very little resemblance to a poet of the modern age. First of all, he did not write or recite a verse, he had a dumbra in his hands, he spoke to us with a steady, semi-melodious voice to the sound of his dumbra. They called chichans "aspiring improvisers". How did they acquire such skills? First of all, since they relied only on their memory and did not need written texts, they memorized a huge stock of folklore. They recited many of the ancient folk songs, dastans, knowing in advance their poetic techniques, how the plot and motifs were chosen in each case, and the rules of their construction and composition. In general, being masters of spoken language, they knew many features that made the ancient language figurative: winged words, say- 
ings, phraseological units, and especially proverbs. Another key to their ability to recite dastans and reproduce them with deep wisdom was that they had that supply of folklore. Proverbs, due to their richness of rhythm and rhyme, served as the main fabric or a ready-made frame in the poetic forms of dastans that helped chichans improvise. Thus, our ancient improvisational poet was freely moving around villages and cities, with a dumbra on his back; if he heard that there was another bard somewhere nearby, he went there, to compete with him, exchanging wisdom and poems. The fact that those proverbs were methodical, argumentative, and exemplary also allowed chichans to participate in judicial procedures. Therefore, chichans were invited not only to the wedding ceremonies but also to resolve different disputable issues inside the country. That is why they were known to help in the time of a conflict!" [Tatar khalyk məkal'ləre, pp. $43-44]$.

Analyzing stylistic features of chichans' work, $\mathrm{N}$. Isanbet drew attention to the fact that poetsimprovisers often used proverbs: "Thus, chichan is a folk poet and a powerful person. As a poet, he creates songs, epics, dastans, and as a ruler, he recites a deeply meaningful poem or a wise saying. To do this, he makes great use of ancient proverbs. He knows a lot of proverbs. Since this genre is so well studied in terms of traditions of its construction and rhythm, it is both easy and natural for him to improvise. Thus, he combines several proverbs into a harmonious composition, turning the plot of a dastan into a powerful argumentation and conflicting motifs. Of course, he does not only mechanically combine proverbs, based on their external similarity, but also, as a poet and authority, creates his own proverbs of this type, cementing improvisation with them, turning them into a holistic work made up of thoughts and feelings. Thus, a new genre of folklore emerges from the proverbs. As can be seen from the dastans, it is called capblt /saryn/ (сарнаn /sarnap/ or a proverb pronounced with a higher voice) or mулгаy /tulgau/ (stirring). (Or, just as it is possible to whip heavy cream until butter is made, one can come up with a great idea by mixing proverbs.) In this case the Bashkirs use the word "кобаер дйтү".

Thus, it is no longer just a random construction of proverbs, but it is a creation of a new genre with an even deeper meaning, new quality and power, as a result of extracting wisdom from proverbs and spreading it in a certain direction. [Татаr khalyk məkal'lore, p. 44].
In his work, the encyclopedist lists the names of chichans who lived both in the Golden Horde era and in the nineteenth century around Kazan: "Later, the poetic and linguistic abilities were further divided, and the meaning of the word "chichan" diluted to "a mastery of the spoken language"; it summed up such meanings as a witty orator and someone who holds events and resolves disputes. Nevertheless, the tradition of composing poems without a pause along with the sounds of a dumbra, using half-verses, half-songs, has remained with the poets of nomadic tribes until now. The Kazakh and Kyrgyz folk poets, for example, Dzhambul, Tuktagul, based their works on these traditions. They are no longer called chichans or poets, but aqyns. Aqyn, according to Radlov, is derived from the same word khaqim (ruler). If this is true, then there is no division into poetry and wisdom in this word, there is both a poet and a sage; that is, it has the same meaning as a chichan. Thus, in the word chichan we find poetry and wisdom as a unity, in a state of syncretism. And this tradition did not fade away until the beginning of this century. For example, Tatar Sabirzhan aqyn from the village of Menger, Baychigavi aqyns from the village of Baychiga in the Laishevsky district, and the poet Akmulla left for the Kazakh SSR at the end of the nineteenth century, and their works, created in the continuous competition with local aqyns, indicate that the custom of singing to the sound of a dumbra and telling poems which are full of wisdom paved their way to written poetry. Akmulla said, "Wisdom comes from poets," meaning that he considered poetry and wisdom indistinguishable, but he, as an ancient bard who brought poetry and authority together, was the one who showed his ability to write and improvise poetry. If we take the works of Majit Gafuri, who used Akmulla's methods, for example, his "Seber timer iuly" ("The Siberian Railway") or, in particular, "Iash' gomerem" ("My Young Life"), then we will see that he also followed the poetic tradition of Kazakh aqyns. I do not know if Gafuri later was influenced by Tukay, but for some reason, he stopped creating in this style; however, Tukay highly appreciated his "Iash' gomerem", which was written in that poetic tradition. These works of Gafuri, like Akmulla's, are rich in proverbs and aphorisms, as an example of how he sought to combine poetry and authority using wisdom in his poetic verse. But here it must be said that these poets-influencers distanced from the ancient chichan's use of proverbs in a straight-forward and free way, instead, they used a verse of eleven or twelve syllables of the Kazakh 
epic form, which differs from the methods of dastanism" [Tatar khalyk məkal'ləre, p. 46].

In his collection "Татаr khalyk халык məkal'ləre", Nakie Isanbet cites 30 proverbs on the topic "Masters of artistic speech, chichans, abyzs, orators", and formulates it in a separate paragraph [Isənbət, Taтar khalyk məkal'ləre, pp. 333 - 334].

In the scientific article "Татар халык дастанының 500 еллыгы” (“The 500th Anniversary of the Tatar Folk Dastan"), Isanbet gives the following description of the masters of the artistic language: "As to how such great folk works as dastans were performed: they required great skill and attention, in ancient times they were performed by professional folk singers (жыраулар) and chichans, masters of words, with the help of such musical instruments as dumbra, dutar, kubyz or saz [Idegəi]. In his commentary to the summary of "Idegəi" ("Edigu") N. Isanbet wrote: "Chichan was a master of words, an orator. In Tatar history, among the chichans who acted at the state level, there was Jamukai Chichan, who opposed Genghis Khan, and Jirancha Chichan, who lived in the Golden Horde during the time of Janibek Khan. [Idegəi, p. 82].

A beautiful image of the chichan is created in N. Isanbet's dastan and his tragedy of the same title. Old Subra (literal translation):

"Кондыздай теше саргайган,

Азулар теше бушаган,

Йөз туксан биш яшәгән

Сыпыра санлье ерау бар,

Үзенда утыз ханның гомере бар

Берса-белмаса бу эмне

Субра белер бу эшне” [Idegəi, pp. 57 - 58]

His teeth are yellow now,

His sharp teeth are loose,

He has lived 195 years,

He is a majestic bard,

He has survived 30 khans,

If you do not know anything,

The bard would know the answer.

The folklorist explains the origin of this hero's name as follows: "Cbinыра сыннльl, according to Valikhanov's definition, given in his explanatory Kara-Kalpak dictionary compiled in 1841 , means "sweeper", that is, a person who can reveal all secrets and destroy them away one by one. In our opinion, the words Coinыра, Субра, Сабра, Caфардаy, found in variations, should be related to each other. The words "cyn", "сыббырдак” mean beautiful, handsome. So, for example, the Siberian Baraba Tatars, when a groom covers a bride's face, sing the following verse (literal translation):
Сыбырдак буйль яшь егет

Жилеп инәр, яр, яр.

A handsome fellow

Will soon be along.

Apparently, there is a connection between the word "Сыбырдак" and the name of this verse "Сафардау", "Сафардак" in the Idegai version, recorded by Radlov from the Baraba Tatars. That is, the names "Субра", "Субрау" must have been pronounced as "Суп - ерау" (Sup - erau) meaning a handsome singer. After all, in the dastan, published by Berezin as a Turkmen version, we see that the name of this singer is "Хубра" (Khubra). If this is related to the word "Хубераy", it will still mean "a handsome singer" as a nickname for a folk singer, a bard. As we have mentioned above, it has been preserved in the Nogai, Kara-Kalpak and Tatar versions (literal translation):

Суп аякльи, суп бүрекле,

Сыпьира сынлы суп ерау.

A presentable, beautifully clad

Majestic bard.

If the names Sabrau and Safardau are distorted variants of Safardak or Farazdak, then we have the name of the Arabic classical poet Farazdek. In our opinion, this name has nothing to do with the Arabic classical poet" [Idegəi, pp. 57-58]

According to the observations of the folklorist F. Urmanche, the section of the dastan, dedicated to the songs of Subra, is "one of the best sections of the legend not only in terms of its artistic value, but also in the development of the plot" [Urmanche, p. 66]. In N. Isanbet's composite text "Idegəi", the hero is 195 years old. He is "not only an old-fashioned fortune-teller but also an extraordinarily intelligent and experienced singer". Without performing any magical actions, shamanism, witchcraft, without referring to any magic books, only thanks to his observations he understands who Kobogyl is [Urmanche, p. 66]. The prophecy of the old Subra, according to F. Urmanche, in terms of its form resembles толгау (tolgau) - reflection or meditation, which is one of the methods used by aqyns. Poetic lines, which are close to aphorisms in terms of their form, immediately attract the audience's attention. The hero himself does not hide that he makes use of the traditions of ancient chichans. Old Subra tests Zhanbay, Edigu and Tuktamysh to see if they know the history of their ancestors and whether they have the qualities of the heroes from epic stories (courage, determination, wisdom, self-confidence, intelligence).

In his song, to cover Edigu in glory, Old Subra creates not only the official political history of the 
Golden Horde but also a gallery of heroes "of all the Turkic-Mongolian world, from Ancient Mongolia to Central Asia and the Central and Lower Volga" [Urmanche, p. 61].

Edigu's portrait, depicting old Subra's height and beauty, his prophetic face, courage and bravery, emphasizes such qualities as wisdom and fortune-telling inherent in chichan-improvisers. In terms of style, the divinity of Subra, according to F. Urmanche, does not differ from the general epic style of the dastan and is almost entirely based on the traditions of the Turkic epic poetry [Urmanche, p. 64].

Also noteworthy are the qualities of the improvisational poet's character, described by Tuktamysh, the hero of N. Isanbet's tragedy "Idegəi” (1941): “Кем соң ул? Шагыйрь! Әнә ул килә. Нинди куәт бар соң аның кулында? Тел. Шагыйрьнең тавышы көчле. Моннан кычкырса, Әстерханга ишетелә. Мин аларны Yз гомеремда бик күп күрдем. Алар безне урынльг да, урынсыз мактыйлар. Шуның каршына зур бүләкләр өмет итәләр. Шулай да шагыйрь вакытлы кычкыра белсә генә яхшы. Вакытсыз кычкырган әтәчне суеп ашыйлар" ("Who is he? A poet! There he comes. What kind of power does he possess? Language. A poet's voice is loud. If he shouts from here, he will be heard in Astrakhan. I have seen them a lot in my life. They praise us both appropriately and inappropriately. Great rewards are expected in return. And yet it is best if a poet knows when the best time comes to speak. The rooster that cries prematurely gets eaten first") [Isənbət.,Әsərlər, II т., p. 119]. In the tragedy, old Subra forces Tuktamysh to greet and welcome him on the khan's horses. Khan mentions that the improvisational poet he knew before did not dare to do so.

The image of chichan plays a key role in $\mathrm{N}$. Isanbet's comedy “Жирән чичән белән Карачәч сылу” (1942) [Isənbət, Әsərlər, II т., pp. 261-352]. "We and other Turkic peoples have preserved many legends and notes about these mysterious words and deeds of Zhiran (Ginger-Haired) Chichan and the Karachach (Dark-Haired) Beauty. Zhiran Chichan was a man who lived in Sarai, the Volga region, in the $14^{\text {th }}$ century", wrote N. Isanbet in 1967 [Isənbət, Tatar khalyk tabyshmaklary, p. 31]. The book of riddles includes "Сәрвиназ" (“Sarvinaz”), “Айбикә” (“Aibika”), “Ачы булса да татлы ни? Татлы булса да ачы ни?” (“If That Is Sour, What Is Sweet? If That Is Sweet What Is Sour?”), “Кемнең үлүе нәрсәгә тиң” (“What's So Special about a Goat's Head?"), riddles and anec- dotes associated with the name of Zhiran Chichan, the collector and compiler of riddles and fairy tales [Isənbət, Taтar khalyk tabyshmaklary, pp. 439 444, 450 - 456]. According to N. Khanzafarov, "using many of these riddles and fairy tales imaginatively, $\mathrm{N}$. Isanbet managed to create a great plot and a fascinating drama". "Zhiran Chichan, who has nowhere to live, amazes the Khan with his wisdom. He takes Yangura's clothes and money, gives her a mahr, pays wedding expenses, and even puts on Yangura's clothes and beats her son to bring him back" [Khanzafarov, p. 89].

"Zhiran Chichan wins Tokmach city, disputes between the countries are resolved in a peaceful manner. The recognition of Zhiran Chichan's contribution to the country comes together with the recognition of his human and personal rights". The chichan considers himself happy because he has his freedom, which is more expensive than all the pearls, and because he has the love of his life who is "more expensive than the Khan's treasury". "Here we can say that the main features of folk characters are the worship of the cult of wisdom, patriotism, love of personal freedom and selfesteem" [Khanzafarov, p. 90].

In the play, a girl named Tutiya describes the role of the improvisational poet Zhiran of Kazanbash in society as follows: "тел остасы чичән! Аның бер телен ишетү өчен гена да мәйданнан мәйданга ат жсибәреп кенә алдыралар иде" (literal translation: "a master of language, chichan! They would rush the horses to the front of the square just to hear his speech") [Isənbət, Жirən-chichən..., p. 264]. Tudyq Zhingy describes in detail what he was busy with: "Әстерхан ягында, ди. Думбра чиртеп, акын булып, казакъ арасында йөри, ди" (literal translation: "Hе says he is somewhere in Astrakhan. He walks among Kazakhs, playing his dumbra and being an aqyn.") [Isənbət, Жirən-chichən..., p. 265].

Karachach, who becomes famous in the maidan, suits him very well: "a chichan girl" [Isənbət, Жirən-chichən..., p. 265]. Through the image of this girl, the playwright "embodies the ideal image of a wise, charming and honest woman" [Khanzafarov, p. 87].

The image of the chichan can also be found in $\mathrm{N}$. Isanbet's children's fairy tale "Бәрәзә песие Мыраубай батыр мажаралары” [Isənbət, Maraubai batyr, pp. 5 - 115]. In this work, the master of words is a cunning fox:

Менә төлке мактый хәзер Мыраубайны,

Теле белән алмак була урап аны,

Мырау моны астан гына күзли сынап, 
Шундый чичән, акылльммы бу, ди, чынлап?

(literal translation: Here is the fox praising Maraubai now / he tries to wrap him up with his tongue/ Marau tries to test him / Such a chichan, is he really smart? he wonders/) [Isənbət, Maraubai batyr, p. 51].

\section{Results}

Nakie Isanbet met chichans and poetsimprovisers during his folklore expeditions. He began collecting works of folk oral art at the age of 10 when he was a student of a madrasah. Nakie Isanbet believed that chichans were the keepers of traditional foundations of chichan art and the spiritual culture of society; therefore, in his scientific and literary works, he did his best to perpetuate outstanding representatives of the chichan tradition, their performance skills, peculiarities of communication with the audience and the poetics of their works. His positive influence on the fate of Blind Farrakh speaks of the scientist's concern about the problem of chichan art (the biography of the improvisational poet, his repertoire, its content and the issues raised in his works, his performing skills and its features, the poetics of his lyrical works). In his scientific articles, the scholar proves that chichans were not only masters of rhetoric, but also tribune poets whose words reflected the wisdom of the people. Analyzing the manuscripts and materials of folklore expeditions, N. Isanbet identified and perpetuated a broad list of the names of chichans who lived for a significant period of history: from the Golden Horde era to the middle of the $20^{\text {th }}$ century. The scholar was the compiler of folklore collections, which included examples of the Turkic epic poetry traditions, as well as collections of texts from the epic heritage of the Turkic peoples ("Idegəi", "Iekəi belən Moradym”).

\section{Conclusion}

From the 1920s to the 1970s, a great deal of work was done by N. Isanbet to systematize information about Turkish folk singers (bards, chichans, sasans, aqyns) and musicians as well as their work. The scientist made a significant contribution to the study of topical problems of folklore studies, Turkic linguistics, and literary studies. Not a single serious scientific work, devoted to the study of the Turkic peoples' folklore, can be carried out without including references to his publications. From the point of view of scientific ethics, it is unacceptable to ignore $N$. Isanbet's contribution to the study of the phenomenon of chichan art and improvisation in Turkic culture.

\section{References}

Amineva, Z. R. (2011). Razvitie traditsii sesenov v iugo-vostochnoi territorii Bashkortostana na sovremennom etape [Development of the Sesens' Traditions in the Southeastern Territory of Bashkortostan at the Present Stage]. Vestnik BGU. T. 16, No. 3(I), pp. 1052 - 1054. Ufa. (In Russian)

Bakirov, M. Kh. (1999). Genezis i drevneishie formy obshchetiurkskoi poezii: avtoref. dis. ... d-ra filol.nauk [Genesis and the Most Ancient Forms of General Türkic Poetry [Text]: Doctoral Thesis Abstract]. M. Kh. Bakirov. Kazan', KGU, 96 p. (In Russian)

Burangulov, M. A. (1995). Zaveshchanie Sesena [Sesen's Will]. Mukhametsha Burangulov. 352 p. Ufa, izd-vo "Kitap". (In Bashkir)

Fərrəkh Dəүlətshin. "Bashкort sasəndare" iyiiyntyzynda (1953) [In the Collection of Works "Bashkir Bards"]. Өfe, Bashкortostan kitap nəshriəte. (In Bashkir)

Gaziev, I. M. (2008). Zarozhdenie professionalizma v muzykal'noi kul'ture drevnikh tiiurkov [The Origin of Professionalism in the Musical Culture of the Ancient Turks]. Vestnik Chelyabinskogo gosudarstvennogo pedagogicheskogo universiteta. No. 12, pp. 179 - 194. (In Russian)

Iarmi Səte (Isməgyilev) (1956). Istalegem [My Memory]. Đzəbi Bashkortostan. No. 3, mart. (In Tatar)

Iarullin, A. (2006). Pamiat' o nom zhiva (K 120letiiu so dnia rozhdeniia narodnogo poeta Bashkortostana) [We Keep the Memory of Him Alive (on the $120^{\text {th }}$ Anniversary of the People's Poet of Bashkortostan)]. Iuldash. 4 maia. (In Russian)

Idegai: tatar halyk dastany (1940) [Idegey: Tatar Folk Epic]. N. Isənbət жyinamasy. Sovet ədəbiiaty. No. 11, pp. 39-76. (In Tatar)

Isənbat, N. (1988). Osarlar $4 \mathrm{~m}$. [Works in 4 Volumes]. T. 2. 416 p. Каzaн', Tat.kitap. nəshr. (In Tatar)

Isənbət, N. (1988). Әсәрләр $4 \mathrm{~m}$. [Works in 4 Volumes]. T. 3. 431 p. Каzaн', Tat.kitap. nəshr. (In Tatar)

Isənbət, N. (1970). Tatar halyk tabyshmaklary [Tatar Folk Riddles]. 568 p. Каzaн', Tat.kitap. nəshr. (In Tatar)

Isənbət, N. Ber darvishney iul dəftəre [One Dervish's Travel Book]. N. Isənbətneң shəkhsi arkhivy. Kuliazma. 79 p. (In Tatar)

Isənbət, N. (1960). Minem iazuchy buluym həm halyk iæçatyn oirənyem [Being a Writer and Studying Folk Art]. N. Isənbətneң shəkhsi arkhivy. Kuliazma. Mashinkada basylgan. 5 p. (In Tatar)

Isənbət, N. (1974). Maraubai batyr [The Brave Maraubai]. 208 p. Каzaн', Tat.kitap. nəshr. (In Tatar) Iyrz̧ar ham bayetter: Orders of khalyк yyrsyhy Furrah yyrзary ham bayettare (1939) [Songs and Poems: The Honored Poet Farrakh's Folk Songs and Poems]. 112 p. Өfe, Bash. kitap. nəshr. (In Bashkir)

Kashgari, M. (2006). Slovar' tiurkskikh narechii : (Divan lugat-at tyurk, XI v.) [Dictionary of Türkic Dialects: (Divan lugat-at Türk, $11^{\text {th }}$ century)]. Pervyi 
perevod na rus. iaz. 1300 p. Almaty, Dayk Press. (In Russian)

Khəbibullin, F. F. (2017). Farrakh Daylatshin ezlare builap [Following in the Footsteps of Farrah Davletshin]. Kуzyl Таң. 19, 21 dekabr'. (In Tatar)

Khəbibullin, F. (2017). Alsalar da kyzemne, birmadem min syzemne ... (Bashkortstannyң halyk chachəne Furrakh Daylatshinnyң tuuyna - 130 el [Although They Took My Eyes, I Have My Words ... $\left(130^{\text {th }}\right.$ Anniversary of the People's Bashkir Bard Farrakh Davletshin]. Kyzyl Таң. 26, 28 gyinvar. (In Tatar)

Khəbibullin, F. (2018). Sukyr Farrakh [Blind Farrakh]. Mədəni жоmga. 18 mai. (In Tatar)

Putilov, B. (1997). Epicheskoe skazitel'stvo: Tipologiia $i$ etnicheskaia spetsifika [Epic Works: Typology and Ethnic Specificity]. 296 p. Moscow, GRVL. (In Russian)

Radlov, V. V. (1911). Opyt slovaria tiurkskikh narechii [Experience of Compiling the Dictionary of Turkic Dialects]. T. 4. V. V. Radlov. St. Petersburg, tip. Imp. akad. nauk, 2230 stb. (In Russian)

Sageeva, G. Kh. (2007). Traditsionnaia terminologiia tatarskoi muzykal'noi kul'tury: semanticheskaia rekonstruktsiia: avtoref. dis. ... kand. iskusstvovedeniia [Traditional Terminology of the Tatar Musical Culture: A Semantic Reconstruction: Ph.D. Thesis Abstract]. G. Kh. Sageeva. Kazan', TGGPU, 26 p. (In Russian)

Sasəndең kәңдаshtəre (1947) [The Bard's Advice]. 63 p. Өfө, Ваshкortostan kitap. nəshr. (In Bashkir)

Sasan tauyshy (1967) [The Bard's Voice]. 18 p. Өfө, Ваshкоrtostan kitap. nəshr. (In Bashkir)

Sultangareeva, R. (2007). Bashkirskaia shkola skazitel'stva i sovremennost' [Bashkir School of Storytelling and Modernity]. Vatandash. No. 6, pp. 164-171. Ufa. (In Russian)
SYz tabuchi sukyr Forrakh əygəməlare: $N$. Isənbətney "Farrakh Kyrlary turnda" digan makalase belən (1928) [Blind Farrah's Interviews: N Isənbət's Article Entitled “On Farrah's Songs"]. 32 p. Ufa, "Bashkniga" həm Bashnarkompros nəshere. (In Tatar)

Tatar halyk mokallare: T. 1. (1959) [Tatar Folk Proverbs]. Жyechu həm tezyche N. Isənbət. 916 p. Kazan, Tat. kitap. nəshr. (In Tatar)

Ukaz Prezidiuma Verkhovnogo Soveta Bashkirskoi ASSR Ob ustanovlenii zvaniia "Narodnyi sesen Bashkirskoi ASSR" (1944) [Decree of the Presidium of the Supreme Soviet of the Bashkir ASSR On the Establishment of the Title "People's seseng of the Bashkir ASSR"]. Krasnaia Bashkiriia. 19 aprelia. (In Russian)

Urmanche, B. (1969). Isənbətney uryny [ Isənbət's Place]. Kazan utlary. No. 12, pp. 131 - 133. (In Tatar)

Urmanche, F. (1999). Narodnyi epos "Idegei" [Folk Epic "Idegei"]. 200 p. Kazan, Fən. (In Russian)

Vorontsov, M. (1939). Narodnyi poet Bashkirii [People's Poet of Bashkiria]. Narodnoye tvorchestvo. No. 3, pp. 46-48. (In Russian)

Vəliullina, F. M. (2007). “Idegəy” dastanynda milli-myfologik hom dini motivlar [NationalMythological and Religious Motifs in the Epic "Idegei"]. F. M. Valiullina. 180 p. Kazan, Dom pechati. (In Tatar)

Zhirmunskii, V. M. (1964). Sredneaziatskie narodnye skaziteli: Traditsii $i$ tvorcheskaia improvizatsiia [Central Asian Folk Storytellers: Traditions and Creative Improvisation]. V. M. Zhirmunskii. (VII Mezhdunarodnyi kongress antropologicheskikh i etnograficheskikh nauk, Moskva, avg. 1964 g.) 13 p. Moscow, Nauka. (In Russian)

\title{
НӘКЫЙ ИСӘНБӘТ ЧИЧӘНЛЕК СӘНГАТЕ ТУРЫНДА
}

\section{Миләүшә Мөхәммәтжан кызы Хәбетдинова,} Казан федераль университеты, Россия, 420008, Казан ш., Кремль ур., 18 нче йорт, mileuscha@mail.ru.

\section{Фәнүз Әфгал улы Хәбибуллин, “Кызыл таң” редакциясе, Россия, 450001, Уфа ш., Октябрьнең 50 еллыгы ур., 13 нче йорт,} kiziltan90@mail.ru.

\begin{abstract}
Мәкаләдә энциклопедик галим, фольклорчы, татар әдәбиятының классигы Нәкый Исәнбәтнең төрки мәдәнияттә чичәнлек традицияләрен өйрәнүгә керткән өлеше системалаштырыла. Галимнең төрки халыклар фольклорын өйрәнүгә багышланган теоретик хезмәтләре, фольклор экспедицияләренең халык авыз ижаты әсәрләре жыентыкларында системага салынган материаллары, язучының чичән образы кергән әсәрләре фәнни эшнең материалы булып тора. Анализлана торган текстның үзенчәлеге фәнни эшебезнең өйрәнү
\end{abstract}

\footnotetext{
${ }^{1}$ Фәррах Дәүләтшин ижаты турында материал Ф.Ә. Хәбибуллин тарафыннан әзерләнде.
} 
ысулын билгели (мәдәни-тарихи, семиотик-культурологик, чагыштырма h.б.). Фольклорга караган теоретик хезмәтләрендә Н. Исәнбәтнең чичәннәр ижаты турында тулы күзаллау формалаштыру һәм аларның образларын үзенең әдәби ижатында мәңгеләштерү омтылышы булганлыгы исбатлана. 1920 елларда галимнең Ф. Дәүләтшин белән берлектә башкарган тәжрибәсе аның әсәрләренең жыентыгын бастырып чыгару белән төгәлләнә. Төрки мохиттә чичәнлек феноменын яктырткан соңгы еллар хезмәтләрен анализлау шуны күрсәтә: Нәкый Исәнбәтнең әлеге теманы өйрәнүгә керткән өлешенә хәзерге заман тикшеренүчеләренең хаксыз рәвештә битарафлыгы сизелә.

Төп төшенчәләр: Нәкый Исәнбәт, халык авыз ижаты, төрки халыклар, татарлар, чичән, жырау.

\section{Kepew}

Традицион халык авыз ижатында үзенчәлекле феномен буларак, чичән һәм чичәнлек проблемасы XIX гасырның икенче яртысында төгәлләшеп бетә. Шул ук вакытта сүз, кагыйдә буларак, В. Радлов, П. Рыбников, А. Гильфердинг һәм аларның шәкертләре формалаштырган рус фольклористикасы мәктәбе ирешкән казанышлар турында бара. Совет чорында әлеге феномен белән кызыксыну тере эпос учаклары сакланып калган милли республикаларда дәвам итә. Фольклорчы Б. Путилов билгеләвенчә, эпосның тере традицияләре төрле формада ул чорда Урта Азия, Себер, Ерак Төньяк, Кавказ арты һәм Төньяк Кавказ, Молдавия, Украина, Идел буе, Рус Төньягы, Карелиядә сакланып калган [Путилов].

Төрки мәдәнияттә халык жыраулары-чичәннәре hәм сүз осталары феноменына галимнәр шактый зур игътибар биргән. Тюркологлар акыннар, чичәннәр, абызлар, жыраулар сәнгатен характерлый торган сүзләрнең тезаурусын системага салган ([Радлов, 120 - 121 бб.], [Кашгарый], [Исәнбәт, 333-334 бб.], [Сагеева] h.б.). Жырчы импровизаторлар, чичәннәр сәнгатен өйрәнүгә үз өлешләрен фольклористлар да ([Жирмунский], [Бакиров], [Бурангулов], [Вәлиуллина], ], [Әминева], [Солтангәрәева] h.б.); музыка белгечләре дә кертә [Газиев].

Безнең фәнни эшнең максаты - энциклопедик галим Нәкый Исәнбәтнең әлеге теманы өйрәнүгә керткән өлешен ачыклау.

\section{Фәнни эшнең материаллары һәм ысуллары}

Фәнни эш өчен материал булып, фәнни мәкаләләр, сүзлекләр, фольклор материаллары жыентыклары, Нәкый Исәнбәтнең әдәби әсәрләре хезмәт итә. Без мәдәни-тарихи, семиотиккультурологик, чагыштырма һ.б. фәнни ысуллар кулландык, алар анализлана торган текстның үзенчәлегеннән чыгып билгеләнде.

\section{Фикер алышу}

Безнеңчә, хәзерге заман галимнәре Нәкый Исәнбәтнең чичәннәр - халык жырауларыимпровизаторлар феноменын өйрәнүгә керткән өлешенә лаексыз рәвештә битарафлык күрсәтәләр. Н. Исәнбәт Башкортстанның Малояз дигән татар авылында туган. Мәдрәсә шәкерте булганда, 10 яшендә Г. Тукай үрнәгеннән илһамланып, халык авыз ижаты әсәрләрен жыя башлый. Бакый Урманче күренекле фольклорчы галимнең формалашуына аның “Мөхәммәдия” мәдрәсәсендә укуы, әйләнә-тирә мохите унай йогынты ясаган дип саный: «Бу вакыт «Мөхәммәдия» мөгаллимнәреннән бик мөлаем, бик симпатик кеше Хужа Бәдигый халык тел әдәбиятын жыюга керешкән иде. Халык әдәбиятына мәхәббәт тойгысын шәкертләр күңеленә урнаштырырга тырыша иде. Олуг галим һәм мәгърифәтче Каюм Насыйри халык әдәбиятын өйрәнүче буларак парлак бер эпизод булса, Хужа Бәдигый, шул ук «Мөхәммәдия» дәресханәләреннән чыккан Гали Рәхим, Газиз Гобәйдуллиннар фольклор белән житди шөгыльләнә башладылар» [Урманче Б., 132 б.].

Н. Исәнбәт фольклор әсәрләрен мәктәптә укытучы булып эшләгәндә дә жыя. 1921 елның жәй айлары дип тамгаланган “Бер дәрвишнең юл дәфтәре" дигән көндәлегендә Н. Исәнбәт Ирәндектән ерак түгел Сәет авылында (Башкортстан) Фәйзулла исемле жырау-импровизатор, курайчылар Хөснулла һәм Габделгазиз белән очрашуы турында сөйли, шул вакытта ул 50 борынгы жыр һәм көй язып ала [Исәнбәт, Бер дәрвишның юл дәфтәре, 50 б.].

Фәндә Н. Исәнбәтнең замандашы, күбрәк сукыр Фәррах буларак танылу алган чичән Фәррах Дәүләтшин белән шәхсән танышлыгы турында да киң билгеле. Галим әлеге чичәннең язмышына да йогынты ясый. Өч ай дәвам иткән тәжрибәнең нәтижәсе буларак, импровизатор шагыйрьнең әсәрләр жыентыгы басылып чыгуын атарга була [Сүз табучы сукыр Фәррәх әңгәмәләре]. Кереш мәкаләсендә фольклорчы 
галим житештерүдәге авария вакытында инвалид булып калган халык шагыйре турында болай дип яза: «Авылның иң түбән очында, чокыр башында, киртәсез йортта, кыексыз өйдә ил гарибе көн итә. Ул хәерче түгел, гарип. Шул өйдә берәү ватык гармун тартып, я үзе ясаган скрипкасын уйнаган булып, әкият тә такмаза сөйләп, бәет тә жыр көйләп, зират каенын ягып, кыш уздыра. Аулак өйләргә йөри, кичәләргә бара, клубка да килеп керә. Яз житеп, әзрәк жир-су кибү белән ул сабан туйларга, жыеннарга чыгып китә. Ул шунда бик күп халыкның күңел хажәтен үтәп йөри. Кайгылы кешеләр аңардан бәет чыгарталар, яшьжилкенчәк аңардан әкият, такмаза сөйләтә, жыр чыгарта, уен-көлке суктыра. Ул шунда буш йөрми, осталыгына күрә әз-мәз әжер дә жыеп ала... Илдән-илгә гизеп, ул күрмәгәнишетмәгәнне калдырмый.

Мондый тип гарипләр арасында бик сүзгә бай, халык хикмәтен жыйган тел остасы, зур халык шагыйрьләре очрап куя. Киң халык катлавы үзенең жырчан, дәртле, бай табигатен, үзенең тормыш көен бу шагыйрьләрдән көйләтеп, шуның белән күңел хажәтен үти. Теле, йөрәге белән, Ү3 тормышы белән киң халык катлавыннан ераклашкан укымышлы шагыйрьләрнең күбесенә караганда, билгеле инде, бу «надан» шагыйрьләр халыкка якынрак та торалар, кирәгрәк тә булып чыгалар. Фәррах та шундый тел остасы, халык шагыйрьләреннән берәүсе».

Фәррах кем? Башта әйтим, көтүче, зурайгач завод эшчесе. Анда озак калмыйча, күзләре сукыраеп, тагын кайтып авыл кешесе. Хәзер дә шулай.» [Сүз табучы сукыр Фәррах әңгәмәләре, б. 2].

Сукыр жырчы өчен Н. Исәнбәт белән очрашу чын мәгънәсендә язмыш бүләге була. «Сүз табучы сукыр Фәррах әңгәмәләре» импровизатор шагыйрьнең әдәби биографиясен башлап жибәрә. Фольклорчы галимнең Уфадан Казанга китүе сәбәпле, Фәррах Дәүләтшинның икенче китабы тагын 10 елдан соң гына дөнья күрә. [Орденлы халык йырсыһы Фәррах йырзары һәм бәйеттәре].

Ф. Дәүләтшин әсәрләреннән жыентык төзегәндә, Н. Исәнбәт укучыга аның импровизаторлык ижатының кабатланмас манерасын да житкерергә омтыла: «Мин китап сүзе сөйләмим. / Сөйләр идем белмимен / Китап сөйләргә чакырсагыз да / Килмимен!» [Сүз табучы сукыр Фәррах әңгәмәләре, б. 7].
Сукыр Фәррахның автобиографик мифы аның тормыш юлындагы чынбарлыкка тәңгәл килә ([Воронцов], [Хәбибуллин, Алсалар да күземне...], [Хәбибуллин, Фәррах Дәүләтшин эзләре...], [Хәбибуллин, Фәррах Дәүләтшин], [Ярми Сәете], [Яруллин]). 1939 елның 8-10 февралендә тутырылган «шәхси листогы» hәм автобиографиясеннән күренгәнчә, Фәррах Дәүләтшин 1887 елның 18 гыйнварында (яңа стиль буенча 31 гыйнвар) Уфа губернасы Бөре өязе (хәзерге вакытта Башкортстанның Дүртөйле районы) Иске Уртай авылында ярлы крестьян гаиләсендә туа. Фәррах туганда, әтисенә - 60, әнисенә 18 яшь була. Язмыш Фәррах Дәүләтшинга карата кырыс була: өч яшькә житкәч, әтисе үлә, биш яшендә әнисе, аны ташлап, икенчегә кияүгә чыга. Малай ата бер, әнисе башка булган абыйсы тәрбиясендә кала. Биш-алты яшеннән үз хезмәте исәбенә яши: бала карый, көтү көтә.

Фәррах яшьтән үк жырчыларны, бәетчеләрне һәм әкиятчеләрне тыңларга һәм ишеткәннәрен халыкка сөйләргә ярата торган була. Жир биләүче Кощеевта эшләгәндә, атаклы сүз остасы, әкиятче Шәвәли карт белән аралашу, аның әсәрләрен тыңлау Фәррахка зур йогынты ясый. Шәвәли карттан отып алган әкиятләрне сөйли, аңа ияреп, үзе дә әкиятләр чыгара башлый.

18 яшендә Фәррах Дәүләтшин Чиләбе өлкәсендәге Әшә-Балашов заводына урман кисү эшенә керә. Аннары Екатеринбург тимер юлында кара эшче була. 1908-1910 елларда Бөре өязе жир биләүчеләре Кощеев һәм Лимбурскийларда эшли. Ул Себер тимер юлында кара эшче булып хезмәт итә. Бер елдан соң, Екатеринбургтан ерак түгел урнашкан Богословский заводына күчә, жәен сал агыза, кышын урман кисә. Аннары Гора-Благодатский руднигында бер ел шахтер була. Халык чичәне 1912-1916 елларда «Ак чишмә» кәгазь фабрикасында эшли, шунда пар торбасы шартлап, эссе пар бәреп, сукыр кала.

Шул рәвешле Фәррах Дәүләтшин кабат туган авылына кайта. Фәррахның авылда чәчәргә жире, ашарга икмәге, торырга йорты булмый. Ул жырлар, бәетләр чыгару белән шөгыльләнә һәм шуларны базарларда, жыеннарда, аулак өйләрдә сөйли, халык нужасы турында жырлый, халыкны изүче, аларның хакын ашаучылардан әче көлә. Аны старосталар да, муллалар да, хәтта власть тарафыннан куелган урядниклар да туктата һәм тыя алмый. Сабантуйлардан, базар мәйданнарыннан куалар 
икән, ул яшьләрне кара мунчага алып кереп булса да, аларга үз бәетләрен сөйли. Шул рәвешле гаиләсенең тамагын туйдыра.

«Югалган тай әкияте» (1909) импровизатор шагыйрь ижатының иң гүзәл үрнәкләренең берсе булу белән беррәттән, әсәрнең язылу тарихы аша без аның авторының жәмгыятьтәге абруе турында да белә алабыз.

Язылу тарихы болай була. Ул эшләгән кыргыз баеның бер өер елкысы югала. Бай моңа бик кайгыра, ул Фәррахның сәләтен белеп, бу турыда бәет чыгарырга куша, алар табылса, аңа бер ат бирергә вәгъдә итә. Фәррах бәет чыгара, аны якын-тирәдә халыкка сөйләп йөри, шул рәвешле байның атларын эзләргә бик күп кеше жәлеп ителә. Бераздан тайлар табыла, бай вәгъдәсен үтәмәскә уйлый. Соңыннан Аллаһы Тәгаләнең жәзасыннан куркып, Фәррахка бер ат бирә. Бу ат шагыйрьнең революциягә кадәр кулында булган бердәнбер малы, диләр.

«Фәррах шушы әсәрендә үзенең сүз остасы булуын күрсәтә, үзенә генә хас булган шигырь төзелеше формасын тудыра һәм бу форма аның ижатында бүгенге көнгә кадәр «Фәррах формасы» булып яшәп килә, шомара», - дип бәя бирә тарихчы, фольклорчы, язучы, Башкортстанның атказанган фән эшлеклесе, 1937-1951 елларда Башкортстан тарих, тел һәм әдәбият фәнни-тикшерену институты директоры булып эшләгән Әбүбәкер Усманов [Йырзар һәм бәйеттер, 5-13 б.].

Ф. Дәүләтшин «Нурия бәете»н үзенең иң күренекле әсәрләренең берсе дип исәпли. «Ул бәет белән мин халык арасында танылу алдым. Мине хәтта чит районнарга да махсус бәет сөйләргә чакыра башладылар», - дип яза чичән үзенең автобиографиясендә [Давлетшин]. «Фәррах чичәннең иң күренекле әсәрләренең берсе - «Нурия бәете» тормышта булган вакыйгадан алып язылган. Шулай булуга карамастан, аның гомумиләштерелгән мәгънәсе бик зур. Бәет персонажларының берсе Сания, мәсәлән, Нуриянең югалткан балдагын кеше гомереннән дә өстен куя. Әйбергә, байлыкка табыну аны кешелеклелек сыйфатларыннан бөтенләйгә мәхрүм итә. Нәтижәдә Нурия Сания мәрхәмәтсезлегенең корбанына әйләнә. «Нурия бәете» - фажигале әсәр, ләкин аның фажигасе укучыны кеше булырга чакыра торганнардан», - дип яза галим, әдәбият белгече, тәнкыйтьче Ким Әхмәтжанов [Сәсән тауышы, 3-8 б.].

1930 елда Казанга баруы турында сукыр Фәррахның аерым әсәре бар. Ул «Фәррахның Казанга барган юллары» дип атала. Чичән әсәрләрен алып, бер тиен акчасыз юлга чыга. Сукыр кеше берьялгызы, жәяүләп, Казанга бара. Халыкка бәетләр сөйли-сөйли, тамак туйдырып, авылларда куна-куна, Дүртөйле, Югары Яркәйне үтеп, Минзәләгә житә. Шәһәр базарында үзенә юлдаш таба. Икәүләп Чаллыга барып житәләр. Бер кешегә ялланып, утын яралар. Теге адәм боларны алдый, тиешле акчасын түләми. Шуннан алар аның бакчасындагы бәрәңгесен казып алып ашыйлар. Алабуга, Мамадышны үтеп, Казанга барып житәләр, шунда ул юлдашыннан аерыла. Фәррах Дәүләтшин күренекле татар язучысы Нәкый Исәнбәтнең фатирын эзләп таба.

«Мамадышны үтеп киткәч, ерак түгел Казан да,

Казаннарга барып кергәч, йөримен базарларда.

Иптәшем китте уң белән, үзем киттем сул белән,

Исәнбәтне эзләп таптым, трамвайский юл белән», -

дип яза ул.

Нәкый Исәнбәт аны яхшы каршы ала, ихлас сөйләшә. Фәррах аларда бер кич кунып, иртән Матбугат йортына бара, әмма уңышсызлыкка очрый: анда аның кулъязмаларын алып калалар, ләкин китап итеп чыгармыйлар.

«Фәррах Дәүләтшин, Сәет Исмәгыйлев, Мөхәмәтша Бурангулов кебек әдипләрнең әсәрләре язма әдәбиятка карыймы, әллә фольклорга керәме, дигән мәсьәлә буенча вакытында бәхәсләр дә булып алган иде. Бу - әдәбиятта махсус проблема. Монда фәкать шуны гына әйтергә була: аларның берсе дә хәзерге мәгънәдәге шигырь түгел, республика хөкүмәте тарафыннан бирелгән «халык чәчәне» дигән исем аларның поэтик эшчәнлеген бик дөрес гәүдәләндерә», - дип саный К. Әхмәтжанов. «Фәррах Дәүләтшин ижатына, башлыча, бәет формасы хас. Шунысы кызыклы: стиль һәм строфика жәһәтеннән төрле-төрле булсалар да, бу өч чичәннең күпчелек әсәрләре, жанр булу ягыннан шигырьгә якын торалар. Революциягә кадәр халык ижатының шигырь дигән жанрны белмәвен искә алганда, чичәннәр ижатындагы яңалыкларны ныграк аңларга мөмкин.

Фәррах Дәүләтшин ижатында да яңа поэтик күренешләр байтак. Башкорт фольклорының жанрларын баету һәм төрләндерү өлкәсендә чичәннең күзгә күренерлек хезмәте бар. Кайчандыр кайгы-хәсрәтне чагылдыручы бәет жанрын ул, асылда, одаларга тартым мотивлар белән сугарды. «Чкалов бәете», «Галия кыз 
бәете», «Ватан сугышы бәете», «Стаханов турында» кебек әсәрләрдә бәет поэтикасы аша алдынгы кешеләрнең портреты бирелә. «Талип», «Янгир абзый», «Габдрахман» кебек әсәрләрдә чәчән катлаулы ижтимагый күренешләрне гомум сүзләр аша түгел, ә аерым кешеләр язмышына бәйләп сурәтләү осталыгын күрсәтте. Язма әдәбиятка гына хас булган пародия, эпиграмма кебек жанрларда да көчен сынап карады. «Ялкау», «Чалмалылар», «Гыймай бай», «Алты ялкау бәете» исемле шигырьләрдә юмор һәм сатираның һәйбәт үрнәкләрен бирде.

Күп кенә бәет һәм шигырьләрендә Фәррах бер үк строфадагы юлларның ижекләр саны да төрлечә итеп бирә. Моның белән ул аерым сүз hәм жөмләләргә ныграк басым ясый ала» [Сәсән тауышы, 3-8 б.].

Фәррах Дәүләтшинның жырлары һәм бәетләре китапларга тупланып (1938 елда - «Орденлы халык йырсыһы Фәррах йырзары һәм бәйеттәре» [Йырзар һәм бәйеттер], 1947 елда «Чәчәннең киңәшләре» [Сәсәндең кәңәштәре], 1967 елда - «Чәчән тавышы» [Сәсән тауышы]), зур тиражлар белән бастырып таратыла, ә кайбер әсәрләре, рус теленә тәржемә ителеп, үзәк журналларда, альманахларда басыла. Аның ижаты Башкортстан мәктәпләрендә, педагогия институтларында өйрәнелә.

Чичән ижатының ижтимагый, сәяси hәм сәнгати әһәмиятен искә алып, 1944 елның 14 апрелендә Башкорт АССРы Югары Советы Президиумы указы белән Фәррах Дәүләтшин «Башкорт АССРының Халык чәчәне» дигән мактаулы исемгә лаек була [Указ Президиума Верховного Совета Башкирской АССР].

Кызганыч, М. Воронцов үзенең мәкаләсендә Нәкый Исәнбәт исемен телгә алмый, галимнең эшчәнлеген - сукыр Фәррах жырларын язган “местный грамотей” дип бәяли [Воронцов, б. 48]. Бу “хәтерсезлекнең” тамырларын Нәкый Исәнбәт биографиясендә эзләргә кирәк. М. Воронцовның татар галименең исемен, “жидегәнче" исемлегендә булуы сәбәпле, телгә алмавы мөмкин. 1931 елның 7 февралендә Казанда Г. Кутуй, Н. Исәнбәт, Т. Ченәкәй һәм Г. Минский кулга алыналар. Аларны контрреволюцион оешма төзүдә гаеплиләр. 8 ай буена барган тикшеру көпчәккә терәлә. Г. Минский белән Н. Исәнбәтне 15 апрельдә (“"чыгып китмәү турында кул куйдыртып”) азат итәләр. Г. Кутуй белән Т. Ченәкәйне 16 сентябрьдә, дәлилләр житмәү сәбәпле, прокуратура иреккә чыгара. "Хәтерсезлекнең" икенче сәбәбе дә булырга мөмкин. 1930 елда Нәкый Исәнбәт
Уфадан Казанга яшәргә дип күчеп килә. Башкорт галимнәре Н. Исәнбәт безнең төбәктә жыйган халык ижаты материалларын татар фольклористикасына бүләк итте дип “үпкәлиләр". Галимнең архивында аның 1928 елда СССР Фәннәр Академиясе Башкорт экспедициясенең тел һәм фольклор отрядында фәнни хезмәткәр булуы турында таныклык саклана.

Татар галиме бер радиоинтервьюда үзенең фәнни һәм әдәби эшчәнлегендә халык авыз ижатының тоткан урынын hәм аны өйрәнү тарихын шулай билгели: «Илле ел буена төрле шигырьләр, драмалар һәм башка әсәрләр язуым белән бергә, бу халык ижатын жыю һәм өйрәнүне дә бервакытта да ташламадым. Фольклорны мин әлегәчә күпләп бастырып чыгара алганым юк. Ләкин алар миндә бик күп хәзер.

Мин халык авыз ижатын иң элек үзен бик яратам, аңа бик зур бәя бирәм. Шуның өстенә аны белүем минем язучылык эшемдә һәрвакыт ярдәм итә" [Исәнбәт. Минем язучы булуым һәм халык ижатын өйрәнүем].

Н. Исәнбәт борынгы татар шагыйрьләренең hәм хакимнәренең чәчән/чичән дип аталуларын hәм аларның кабилә-кавем тормышында зур роль уйнауларын борынгы дастаннардан, мәкальләрдән hәм тарихи чыганаклардан күп фактлар китереп дәлилли. «Мәкальләребез турында» исемле хезмәтендә галим чичән сүзенә шундый аңлатма бирә: «Чичән дип аталган кеше хәзер бездә үзе түгел, хәтта сүзнең үзе дә, кулланудан төшеп, авыз ижтында гына калып бара. Х. Бәдигь мәкальләр жыентыгының 1912 елгы басмасында чичән сүзенә «пөхтә, көяз, фырт» дип аңлатма бирә, тик 1926 елгы басмасында гына «сүз остасы» дип дөресли.

Китабының hәр ике басмасында хәтта чечән дип язылган. Бу сүзнең халыкка сүз остасы мәгънәсендә йөрүе билгеле. Ул бик телгә чичән кеше, диләр. Кайбер сөйләшләрдә чәчән формасын да кулланалар. Казахларда - шешен, башкортларда сәсән йөри. Соңгыларда шул исемдә әдәби, рәсемле бер журнал да чыгарылды, һәм тоткарсыз рәвештә жыр чыгарып әйтә алучы берничә халык шагыйренә сәсән исеме бирелде. Монысы безнең өчен тагын да әһәмиятле. Чөнки монысында чичән сүзенең матур сөйли белүче генә түгел, илһами рәвештә, кәгазьгә язмастан, тоткарсыз шигырь әйтүче шагыйрьимпровизатор мәгънәсен дә Үз эченә алуын күрсәтә. Һәм ул тарихлар буенча шулай да. "Чичән" сүзе элек сүз остасы дигәнне дә, жыручы-импровизатор дигән мәгънәне дә 
аңлаткан. Димәк, ул һәр ике профессияне үзендә бергә жыйган кеше, борынгы халык шагыйре дигән сүз» [Татар халык мәкальләре, б. $41-42]$.

Н. Исәнбәт халык арасында кин кулланылышта йөргән мәкальләр, фразеологик гыйбарәләр, дастаннарны анализлау нигезендә чичәннәрнең борынгыдан бирле жәмгыятьтә тоткан урыннарын билгели, импровизатор шагыйрьләрнең халык арасында алыштыргысыз абруе булганлыгын исбат итә: «Бездә дә чичән дигән исемдә зур хөрмәтле халык кешеләре булуы татар мәкальләренең үзләреннән үк күренеп тора: Батыр яуда беленер, чичдн дауда беленер. Димәк, батырлар ил чигеннән килгән яуны бетерүдә беленсәләр, чичәннәрнең телгә осталыгы да ил эчендәге дауларны (конфликтларны) бетергәндә беленә. Чичәннең теле уртак, чибәрнең кулы уртак. Моннан чичәннең сүзе мәгънә һәм хикмәткә, димәк ки, уртак әһәмияткә ия булуы, шуның белән халыкка уртак булуы әйтелә. Аның бу осталыгы эштә һөнәрле кешенең кулына чагыштырыла. Шулай ук борынгы халык дастаннарына караганда, чичәннәрнең сынчы (сынаучы - алдан хәбәр итүче) булулары да бик ачык күренә. Мәсәлән, кабилә һәм феодаллык тормышында кайбер кешенең кемлеген сынап белергә хажәт төшә. Моны белү ул заманда бик жиңел булмаган. Бигрәк тә дәүләт тирәсендәге кешеләрнең хокук дәрәжәләре аның асылы-нәселе кем булуга бәйләнгәнлектән, бу белгечлек аеруча әһәмият казана. Шундый сәләт һәм осталык сорый торган бу эш сынчылык дип аталган. (Бу сүзне хәзерге сынлы сәнгать белән бутарга ярамый.) Сынчылар кешенең йөзенә, кыланышына бераз гына карап торгач та, читләтеп, бер-ике сорау белән аның нәселен, чыгышын, үзенең кемлеген, киләчәк язмышын әйтеп бирергә тиеш булганнар. Пәйгамбәрлек итү шикелле мондый серле-хикмәтле эшнең дә чичәннәр тарафыннан башкарылуы безнең өчен бик әһәмиятле. Мәсәлән, дастаннардан күренгәнчә, олы хан, үзенә жибәрелгән бер илченең кем икәнен ачу өчен, кайдадыр халык арасында яшәгән шундый бер өлкән жырчы чичәнне чакырта. Бу чичәннең яше ике йөзләргә житкән карт булуы (ягъни тормышта күпне күргән, кешеләрне күп сынаган, бай тәжрибәгә ия булган образ), кат-кат чакыртып та, бик ялындырып, алтын арбада мамык түшәкләр өстендә генә килүе, гаять дәрәжәдә мәһабәтлеге, ул мәжлес түрендә беренче урынга утырып, олы хан үзе аның каршында аякчы (савыт-саба биреп торучы; касә сонучы, шәрабче. - acc. $M$. $X$.) булып, кулыннан бал бирүләре бик тәэсирле сурәтләнгән. Ул үзен олы хан алдында бөтенләй иркен, бәйсез тота. Аның үтенечен теләр-теләмәс кенә кабул иткәч, шунда утырган илчене үзенә сиздермичә сыный башлый, югарыда әйтелгәнчә, аңа жиңел генә бер йомыш үтәргә куша, читләтеп кенә, берәр сорау бирә. Йөзенә, кыланышына текәлеп караганнан соң, думбрасын кулына алып, бу әйтелгән илченең үткәнен һәм киләчәген әйтеп, кемлеген ача башлый. Шунысы кызык: ярым көйләп уку, ярым жыр шикелле тезелгән бу сүзләр мәкаль hәм шигъри образларга бай тезмәләрдән тора.

Без мәкальләрнең килеп чыгулары, бер яктан, борынгы сынау, тәжрибә һәм хәтта күрәзәлекләр белән бәйле булганын күргән идек. Монда аның нәкъ шул хасияте жыручы чичән тарафыннан сынауга тотылганын күрәбез, ягъни мәкаль үзе сынаудан туса, аны мәгълүм тәртипләрдә тезә белү һәм шул алымда үзеңнән дә образлы сүзләр куша белү аша сынчылык итеп була дип уйлаган борынгылар кемнең кемлеген дә мәкальчелек белән сынап, ачып була дип эш иткәннәр. Шул сәбәпле без борынгы заманнарда мәкаль һәм аны барлыкка китерү сәләтенең югары бәяләнгәнен, мәкаль ул яшерен, серле, хикмәтле көчләргә ия, мондый алым белән эш итә белүче кеше хәтта ки пәйгамбәр дәрәжәсендә гамәлләр кыла ала дип каралганын күрәбез. Бу яклары белән чичән борынгы грекларның оракулына, мисырлыларның жрецына, гарәпләрнең шәехенә, каһиненә, бездәге багучы, баксы, бәхши, күрәзә, шаман һәм сынчыларга якын тора. Бу жәһәттән без борынгы кабилә тормышы катлауланып, аксакаллар һәм шаманнар инде халыкның тел, тәжрибә һәм хикмәт байлыгын, авыз ижатын үзләренә туплап бетерә алмагач, идея һәм сәнгать өлкәсен шул эшнең аерым осталары булган шагыйрь-чичәннәргә тапшыра башлаулары ихтимал дигән фикердә торабыз.

Билгеле, мондый жыручыларга һәм хакимчичәннәргә борынгылар тәжрибә һәм хикмәтнең сихри көченә ия дип караганнар, шунлыктан аларның исемнәре алдында ханнар да куркып торган һәм чичәннәрнең күңелләрен яулап, алар аша хакимлек жепләрен жәяргә, халык арасында Y3 дәрәжәләрен күтәрергә тырышканнар. Ләкин тарихтан билгеле булганча һәм югарыда китерелгән мисаллардан күренгәнчә, халык шагыйре hәм хакиме булган чичәннәр Ү3 профессияләренә бик зур бәя биргәннәр, тәхет алдында үзләрен вак тотмаган кебек, халык 
күтәрелешләре вакытында аларның хәрәкәт башында торган чаклары да булган. Мондый очракта аларның тел-ижат куәте реаль көчкә әйләнгәнгә, ханнар өчен бу житди куркыныч тудырган. Мәсәлән, шундыйлардан Жамукай чичәннең найманнар күтәрелеше башында торуы һәм, үзенең тел кылычын Чыңгыз кылычына каршы куеп, утыз еллар буе аңар баш бирмичә, күтәрелеш алып баруы билгеле.

Кытай тарихыннан мәгълүм булганча, с а с a н ы г дип (чичән, чәчән, сәсән) аталган кешеләр төрки кавем-кабиләләрнең вәкилләре арасында борын-борыннан очрый hәм халыкның ижтимагый-сәяси хәрәкәтләрендә дә аларның билгеле эз калдырулары күренә. Шулай итеп, бу сүз үз авызыннан шигырьхикмәт чәчә белүче чәчәнме, әллә мәсьәлә чишә белүче хаким мәгънәсендә чичәнме, ул хәтлесен белеп булмый. Ләкин бу сүзнең Кытайдан алып, безнең ошбу жирләргә хәтле таралып яшәгән һәммә төрки халыкларда очравы борынгы кавем-кабиләчелек hәм патриархальлек заманнарында мондый жанр ижатның һәммәсендә дә нык таралган булуын күрсәтә» [Татар халык мәкальләре, б. 42 - 43].

Н. Исәнбәт үзенең мәкаләсендә чичәннәрнең ижади эшчәнлеген жентекләп тасвирлый: «Чичән, жыручы буларак, ничек ижат итә соң? Безгә монда аның шунысын белү әһәмиятле. Дөрес, ул безнең борынгы шагыйрь, ләкин ул бу замандагы шагыйрьгә бик аз охшаган. Иң элек ул шигырьне язып чыгармый, сөйләп тә чыгармый, аның кулында думбра, ул шуның кылларында күтәренке, ярым көйле авазлар белән безгә тоткарсыз тезмә чыгарып сөйли. Ул илһами әйтә белүче импровизатор, дидек. Бу һөнәргә ул ничек ирешә соң? Иң элек ул язусыз, хәтердән генә эш иткәнгә, аның хәтерендә фольклор һәм сүз алымнарының запасы бик зур. Ул борынгы халык жыр дастаннарының күбесен күңелдән әйтә, аларның шигъри алымнарын, сюжет һәм мотивларының һәр очракта ничек сайланышын, төзелеш, композициядәге йолаларын алдан ук белә. Гомумән, сөйләү теленең остасы буларак, борынгы телне сурәтле ясый торган бөтен чараларны канатлы сүз, әйтемнәрне, фразеологияләрне, бигрәк тә мәкальләрне күп белә. Аның шигырьдастаннарны тоткарсыз сөйли алу һәм тирән хикмәтле итеп чыгара белүенең тагын төп сере дә шул запаска ия булуында. Мәкальләр, ритмга һәм рифмага бай булулары сәбәпле, дастан шигъри формаларында төп тукымалар яки әзер кәрәзләр булып хезмәт итәләр, шулар буенча чичән балавызны теләгән якка теләгәнчә суза. Шуның белән безнең ул борынгы шагыйрь-чичәнебез, аркасына думбрасын аскан хәлдә, авыл-шәһәрләр аша бик иркен гизә; кайда тагын шундый бер шагыйрь барын ишетсә, анда барып, мәжлестә аның белән ярышка керә, кара-каршы хикмәт, шигырь әйтешеп жиңешә. Мәкальләрнең кагыйдәчел, дәлилле һәм мисаллы булулары чичәнгә хөкем тәртипләренә катышырга да мөмкинлек бирә. Шуның өчен дә чичән ул туй-мәжлесләр түрендә генә түгел, ил эчендә барган дауызгышларны хәл итешүгә дә чакырып китерелә. Менә ни өчен ул дауда беленə!» [Татар халык мәкальләре, б. 43 - 44].

Чичәннәр ижатының стиль үзенчәлекләрен анализлап, Н. Исәнбәт импровизатор шагыйрьләрнең мәкальләргә еш мөрәжәгать итүенә игътибар итә: «Шул рәвешле, чичән - халык шагыйре һәм хаким кеше. Шагыйрь буларак, ул жыр, эпос-дастан тудырса, хаким буларак, ул тирән мәгънәле шигырь, хикмәтле сүз әйтә. Моның өчен ул борынгы мәкальләр алымыннан бик нык файдалана. Ул искиткеч күп мәкаль белә. Жанрның төзелеш һәм ритм йолалыгын (традицияләрен. - acc. H. И.) бик нык үзләштергәнлектән, бу алым белән тоткарсыз ижат (импровизация. - acc. Н. И.) теземнәре әйтү аңа жиңел дә, табигый дә. Шуның белән ул берише мәкальләрне төзек бер композициядә тезеп, дастан сюжетын куәтле дәлил һәм конфликт мотивларына әверелдерә. Билгеле, ул мәкальләрне, тышкы охшашлыкларына карап, механик рәвештә генә төземи, бәлки, шагыйрь hәм хаким буларак, үзе дә шул типта мәкальләр ясый, алар белән теземне цементлап, бөтен бер фикер һәм хис әсәренә әйләндерә. Шуның белән мәкальләрдән үзенә яңа бер төр фольклор жанры килеп чыга. Дастаннардан күренгәнчә, моны сарын (сарнап яки мәкальләрне берберсенә сарып, күтәренке бер тавыш белән әйтү. - acc. Н. И.) яки тулгау, диләр. (Яки туглау, әйтик, каймакны туглап язып, май төшереп булган кебек, берише мәкальләрдән туглап, олы бер фикер чыгару була. - асс. Н. И.) Башкортлар моны кобаер әйтү, диләр.

Шулай булгач, бу инде мәкальләрнең очраклы теземе генә түгел, бәлки, аларны билгеле бер юнәлештә сару юлы белән хикмәт сөземтәсе чыгару нәтижәсендә, тагын да тирәнрәк мәгънәле, яңа сыйфатлы, көчле бер яңа жанр тудыру дигән сүз» [Татар халык мәкальләре, б. 44]. 
Энциклопедик галим үзенең хезмәтендә Алтын Урда дәверендәге генә түгел, ә XIX гасырда Казан артында яшәгән чичәншагыйрьләрнең дә исемнәрен атап үтә: «Соңга табарак шагыйрьлек һәм тел осталыгы сәләте тагын икегә аерылып, чичән сүзенең мәгънәсе сөйләү теленең осталыгына кайтып калган; ул мәжлесләр тотучы, даулар хәл итүче, сүзгә тапкыр, үткен телле оратор мәгьнәләрен эченә жыйган. Шулай булса да, думбра кыллары астында, аларның ярым сөйләү, ярым көйләү юлы белән сарнап, тоткарсыз шигырь- хикмәт тудыра алу йоласы күчмә кабилә халык шагыйрьләрендә әле дә калган. Казах, кыргыз халык шагыйрьләре, әйтик, Жамбул, Туктаголлар бүгенге көндә дә шул юл белән ижат итеп килделәр. Алар инде чичән дип тә, шагыйрь дип тә түгел, акын дип аталалар. Акын, Радлов аңлатуынча, шул ук хаким дигән сүздән алынган. Бу дөрес булса, димәк ки, бу сүздә шигырь белән хикмәт аерылмаган, шагыйрь дә, хикмәт иясе дә була, ягъни ул да чичән дигән сүз. Шул рәвешле чичәндә без шигырь белән хикмәтне бергә килеш, синкретизм хәлендә табабыз. Бездә дә бу йола шушы йөз башларына хәтле бетеп житмәгән. Мәсәлән, Казан артының Мәңгәр татары Сабиржан акын həм Лаеш ягындагы Байчыга авылының Байчыгави акыннар, шулай ук шагыйрь Акмуллалар шушы XIX йөз ахырларында гына казах арасына китеп, аларның акыннары белән тоткарсыз ярышта тудырган әсәрләре бу думбра кылы астында жырлап-сөйләп шигырьхикмәт әйтү йоласының бездәге язма шигырь көнендә дә үзенә сукмак салып килүен күрсәтәләр. Акмулла: «Сүз чыгар шагыйрьләрдән хикмәт белән», - дигәндә, шигырь белән хикмәтне аерымсыз каравын әйткән булса, үзе дә, шагыйрьлек һәм хакимлекне бергә жыйган борынгы чичән сыйфатында алга басып, шигырьне язып та, тоткарсыз сөйләп тә чыгара белү сәләтен күрсәткән кеше. Шул ук Акмулла алымнары белән әсәрләр тудырган Мәжит Гафуриның баштарак язган «Себер тимер юлы» яки бигрәк тә «Яшь гомерем» дигән әсәрләре алып каралса, аның да казах акыннарының шигырь-хикмәт йоласына ия булганын күрәбез. Гафури соңрак, белмим, Тукай тәэсире астына төшепме, ни өчендер бу юлдан баш тарткан, әмма Тукай аның нәкъ шул акыннар алымы белән язган «Яшь гомерем»енә зур бәя бирә. Гафуриның ул әсәрләре, Акмулланыкы кебек үк, мәкаль һәм афоризмнарга бай булулары, ничек итеп шигырь тезмәсендә хикмәтне файдаланып, активлаштыруның, шагыйрьлек белән хакимлекне бергә жыюга омтылуның үрнәге булып тора. Тик монда безнең бу соңгы хаким-шагыйрьләрнең борынгы чичәннәрчә турыдан-туры ирекле мәкаль тезмәчелеге һәм дастанчылык алымнарыннан аерыла төшеп, унбер-унике ижекле казах өләңчелеге тезмәсен файдалануларын әйтергә кирәк» [Татар халык мәкальләре, б. 46].

Нәкый Исәнбәт үзенең “Татар халык мәкальләре" жыентыгында "Сәнгатьле сөйләм осталары, чичәннәр, абызлар, ораторлар” темасына караган 30 мәкаль китерә, ул аны аерым параграф итеп формалаштырып бирә [Исәнбәт, Татар халык мәкальләре, б. 333 - 334 б.].

«Татар халкы эпосы - “Идегәй” дастанының биш йөз еллыгына» дигән фәнни мәкаләдә нәфис сүз осталарына түбәндәге характеристиканы бирә: «Инде дастан шикелле бөек халык ижатларының ничек башкарылуына килсәк, алар зур осталык һәм игътибар таләп иткәннәр, борынгырак заманда алар профессиональ халык жырчылары (жыраулар. - acc. Н. И.) һәм тел остасы чичәннәр тарафыннан думбра, дутар, кубыз яки саз шикелле музыка кораллары ярдәме белән башкарылганнар» [Идегәй, б. 82]. “Идегәй”нең жыелма текстына шәрехләмәсендә Н. Исәнбәт түбәндәгеләрне яза: «Чичән - тел остасы, оратор. Татар тарихында дәүләт күләмендә эш иткән чичәннәрдән Чыңгызга каршы чыккан Жамукай чичән, Алтын Урдада Жанбик хан чорында яшәгән Жирәнчә чичәннәр билгеле» [Идегәй, б. 61].

Халык чичәненең күркәм образы дастанда hәм Н. Исәнбәтнең шул исемдәге трагедиясендә тудырыла. Ул - Субра карт:

«Кондыздай теше саргайган,

Азулар теше бушаган,

Йөз туксан биш яшәгән

Сыпыра санлы ерау бар,

Үзендә утыз ханның гомере бар,

Берсә - белмәсә бу эшне

Субра белер бу эшне» [Идегәй, б. 57 - 58 б.]

Фольклорчы әлеге герой исеменең килеп чыгышын болай аңлата: «Сыпыра сынлы Вәлихановның 1841дә жыйган каракалпак вариантында аңлатмасында бу сүз - саф себерүче, ягъни бөтен тырнак астындагын ачып, барын да сыпырып бер-бер артлы сөйләп бирүче - дип аңлатылган. Безнеңчә вариантларда күренгән Сыпыра, Субра, Сабра, Сафардау - сүзләре бар да бер бәйләнештә булса кирәк. «Суп», «сыбырдак» сүзләренең гүзәл, матур дигән мәгънәләре бар. Мәсәлән, 
Себердәге бараба татарлары кияү егетен кыз катына япканда:

Сыбырдак буйлы яшь егет

Жилеп инәр, яр, яр, -

дип ерлыйлар. Биредәге «Сыбырдак» сүзе белән шул ук бараба татарларыннан Радлов тарафыннан жыелган Идегәй вариантында бу ерчының «Сафардау», «Сафардак» дип аталуы арасында бәйләнеш бар шикелле. Ягъни «Субра», «Субрау» исеме «Суп - ерау» - гүзәл ерчы мәгънәсендә әйтелгән булырга тиеш. Чөнки Березинның төрекмән варианты дип бастырган Идегәй дастанында без бу ерчының исемен "Хубра" рәвешендә күрәбез. Бусы «Хуберау» сүзенә кайта торган булса, һаман да гүзәл ерчы мәгънәсендә халык ерчысының кушаматы килеп чыга. Алда күрелүенчә, нугай, каракалпак һәм татар вариантларында сакланган:

Суп аяклы, суп бүрекле,

Сыпыра сынлы суп ерау, -

сүзе белән шул фикерләребезне дөресли. Инде Сабрау, Сафардау исемнәре Сәфәрдак яки Фәрәздакдан бозылган булса, бусыннан гарәп классик шагыйре Фәрәздәк исеме килеп чыга. Безнеңчә, бу исемнең гарәп классик шагыйренә һич бәйләнеше юк» [Идегәй, б. 57-58].

Фольклорчы Ф. Урманче күзәтүләренә караганда, дастанның Субра жырауга багышланган бүлеге - “сәнгати яктан гына түгел, ә сюжет үстерелешендә дә риваятьнең иң яхшы бүлекләренең берсе". [Урманче Ф., с. 66]. Н. Исәнбәтнең "Идегәй” жыелма текстындагы геройга - 195 яшь. Ул “күпне күргән күрәзәче карт кына түгел, ә гадәттән тыш зиһенле һәм тәжрибәле жырчы”. Бернинди магик гамәлләр, шаманлык, сихерчелек кылмыйча, магик китапларга мөрәжәгать итмичә, бары тик күзәтүләр нәтижәсендә ул Кобогылның кем икәнлегенә төшенә" [Урманче Ф., с. 66]. Субра картның пәйгамбәрлеге, Ф. Урманче фикеренчә, формасы ягыннан акыннарның бер ижат төре булган толгауны - уйлануны хәтерләтә. Формасы ягыннан афоризмнарга якын шигъри юллар тыңлаучыларның игътибарын шунда ук жәлеп итә. Герой үзе дә борынгы чичәннәр традицияләренә таянуын яшерми. Субра карт Жанбайны, Идегәйне һәм Туктамышны атабабалар тарихын белү-белмәүләрен, эпик кыйссалар геройларына хас сыйфатларга (кыюлык, тәвәккәллек, зирәклек, үз-үзеңә ышанганлык, зиһенлелек) ия булу-булмауларын тикшереп карый.

Субра карт үзенең жырында Алтын Урданың рәсми сәяси тарихын гына түгел, Идегәйне данга күмәр өчен, “Борынгы Монголиядән башлап, Урта Азия белән дәвам итеп, Урта һәм Түбән Иделгә кадәр бөтен төрки-монгол дөньясындагы” батырлар галереясен тудыра [Урманче Ф., с. 61].

Субра карт Идегәй портретында зифа буй һәм чибәрлек, пәйгамбәр йөзле булу, кыюлык hәм батырлык белән беррәттән, чичәнимпровизаторга хас зирәклек һәм күрәзәчелек сыйфатларын да ассызыклый. Субра картның күрәзәлеге, Ф. Урманче фикеренчә, стиле ягыннан дастанның гомуми эпик стиленнән аерылып тормый һәм тулысынча диярлек төрки героик эпос традицияләренә нигезләнә [Урманче Ф., с. 64].

Жырчы-импровизатор образының Н. Исәнбәтнең "Идегәй” (1941) трагедиясе герое Туктамыш теле белән әйттерелгән сыйфатлары да игътибарга лаек: «Кем соң ул? Шагыйрь! Әнә ул килә. Нинди куәт бар соң аның кулында? Тел. Шагыйрьнең тавышы көчле. Моннан кычкырса, Әстерханга ишетелә. Мин аларны үз гомеремдә бик күп күрдем. Алар безне урынлы да, урынсыз мактыйлар. Шуның каршына зур бүләкләр өмет итәләр. Шулай да шагыйрь вакытлы кычкыра белсә генә яхшы. Вакытсыз кычкырган әтәчне суеп ашыйлар» [Исәнбәт, Әсәрләр, II т. б. 119]. Трагедиядә Субра карт Туктамышны хан атларында каршы алырга һәм сәламләргә мәжбүр итә. Хан моңа кадәр үзенә таныш булган импровизатор шагыйрьләрнең болай кыланырга жөрьәт итмәве турында әйтә.

Чичән образы Н. Исәнбәтнең «Жирән чичән белән Карачәч сылу» комедиясендә төп герой булып китә (1942) [Исәнбәт, Әсәрләр, III т., б. 261 - 352]. «Жирән чичән һәм Карачәч сылуның бу табышмаклы сүз һәм эшләре турында бездә һәм башка төрки халыкларда сакланган риваятьләр күп, язып басылганнары да бар. Жирән чичән - Идел буенда, Сарайда XIV гасырда яшәгән кеше», - дип яза 1967 елда Н. Исәнбәт [Исәнбәт, Татар халык табышмаклары, б. 31]. Табышмаклар китабына жыючысы hәм төзүчесе тарафыннан Жирән чичән исеменә бәйле «Сәрвиназ», «Айбикә», «Ачы булса да татлы ни? Татлы булса да ачы ни?», «Кемнең үлүе нәрсәгә тиң» кебек табышмак-әкиятләр, табышмак-мәзәкләр кертелгәннәр [Исәнбәт, Татар халык табышмаклары, б. 439 - 444, б. 450 - 456]. Н. Ханзафаров фикеренчә, «мондый табышмакларның, әкиятләрнең бик күбесен ижади файдаланып, Н. Исәнбәт сюжетлы, мавыктыргыч сәхнә әсәре ижат итүгә ирешкән». «Торыр жире дә булмаган Жирән 
чичән үзенең зирәк акылы белән ханны хәйран калдыра. Ул Янгура бинең киемнәрен, акчасын отып, мәһәр бирә, өйләнү чыгымнарын түли, хәтта би киемнәрен киеп, аның улын кыйнап кайтара» [Ханзафаров, б. 89].

«Жирән чичән Токмач шәһәрен ота, илләр арасындагы бәхәс тынычлык белән хәл ителә. Жирән чичәннең ил алдындагы хезмәтен тану аның кешелек, шәхси хокукларын тану белән бергә туа». «Чичән үзен бәхетле саный, чөнки бөтен энже-мәржәннәрдән дә кыйммәтрәк иреге бар, чөнки аның «хак казнасыннан кыйммәтрәк» сөеклесе бар». «Биредә халыкчан характерларның төп сыйфатлары - акыл культына табыну, патриотлык, шәхси ирек сөю, горурлык дип әйтә алабыз» [Ханзафаров, б. 90].

Тутыя исемле кыз пьесада импровизатор шагыйрь Казанбаш Жирәненең жәмгыятьтәге урынын болай дип тасвирлый: «Тел остасы чичән! Аның бер телен ишетү өчен генә дә, мәйданнан мәйданга ат жибәреп кенә алдыралар иде» [Исәнбәт, Жирән чичән..., б. 264]. Тудык жиңги аның нәрсә белән шөгыльләнүен жентекләп тасвирлый: «Әстерхан ягында, ди. Думбра чиртеп, акын булып, казакъ арасында йөри, ди» » [Исәнбәт, Жирән чичән..., б. 265].

Мәйданда дан алган Карачәч тә аңа туры килеп тора: «чичән кыз» [Исәнбәт, Жирән чичән..., б. 265]. Бу кыз образы аша драматург «зирәк, сөйкемле, турылыклы хатын-кыз турындагы идеалны гәүдәләндерә». [Ханзафаров, б. 87].

Чичән образы Н. Исәнбәтнең балалар өчен язылган «Бәрәзә песие Мыраубай батыр мажаралары» әкиятендә дә очрый [Исәнбәт, Мыраубай батыр., б. 5 - 115]. Әлеге әсәрдә тел остасы - хәйләкәр төлке:

Менә төлке мактый хәзер Мыраубайны,

Теле белән алмак була урап аны,

Мырау моны астан гына күзли сынап,

Шундый чичән, акыллымы бу, ди, чынлап?

[Исәнбәт, Мыраубай батыр, б. 51].

Икенче очракта халык чичәне ролен мөнәжәтләрне оста итеп башкаручы Гөл әби башкара: «Хәммәдия» мөнәжәт көйләп карый». [Исәнбәт, Мыраубай батыр, б. 98].

\section{Нәтижәләр}

Чичәннәр hәм импровизатор шагыйрьләр белән Нәкый Исәнбәт фольклор экспедицияләре вакытында таныша. Халык авыз ижаты әсәрләрен ул мәдрәсә шәкерте булганда, 10 яшендә жыя башлый. Нәкый Исәнбәт чичәннәр - чичәнлек сәнгате жәмгыятьнең рухи мәдәни- ятенең тардицион нигезләрен саклаучылар дигән фикердә тора, шуңа күрә үзенең фәнни хезмәтләрендә һәм әдәби әсәрләрендә чичәнлек традицияләренең күренекле вәкилләрен, аларның башкару осталыгын, аудитория белән аралашу үзенчәлекләрен, әсәрләренең поэтикасын мәңгеләшетерергә омтыла. Сукыр Фәррахның язмышына уңай йогынты ясавы галимнең чичәнлек проблемасына житди игьтибары турында сөйли (жырау-импровизаторның биографиясе, репертуары, әсәрләренең эчтәлеге hәм проблематикасы, башкару осталыгы һәм үзенчәлекләре, текстларының поэтикасы. - acc. $M . X$.). Бер төркем фәнни мәкаләләрендә галим чичәннәрнең нәфис сүз осталары гына булмыйча, hәр сүзендә халыкның зирәк акылы чагылыш тапкан трибун шагыйрьләр икәнлеген дә исбатлый. Фольклор экспедицияләренең кульязма мирасын һәм материалларын анализлап, Н. Исәнбәт тарихның зур бер аралыгында - Алтын Урда дәвереннән башлап, XX гасыр урталарына кадәр яшәгән чичәннәрнең исемнәрен барлый һәм мәңгеләштерә. Галим төрки чичәнлек тардицияләре үрнәкләре кергән фольклор жыентыкларын төзүче була, шулай ук төрки халыкларның эпик мирасының жыелма текстларын булдыра («Идегәй», «Идекәй белән Морадым»).

\section{Йомгаклар}

1920 еллардан алып, 1970 елларга кадәр Н. Исәнбәт тарафыннан төрки халык жырчылары hәм музыкантлары (жыраулар, чичәннәр, сисәннәр, акыннар), шулай ук аларның ижатлары турында мәгълүматларны системага салу буенча зур эш башкарыла. Галим фольклористика, төрки тел белеме һәм әдәбият гыйлеменең актуаль проблемаларын өйрәнүгә саллы өлешен кертә. Төрки халыкларның авыз ижаты мәсьәләләрен өйрәнүгә багышланган бер генә житди фәнни хезмәт тә аның гыйльми эшчәнлегенә мөрәжәгать итмичә башкарылмый. Н. Исәнбәтнең төрки мәдәнияттә чичәнлек һәм импровизаторлык феноменын өйрәнүгә керткән өлешен игътибарсыз калдыру фәнни этика ноктасыннан жинаятькә тиң һәм моңа юл куярга ярамый.

\section{Әдәбият}

Аминева 3. Р. Развитие традиций сэсэнов в юговосточной территории Башкортостана на современном этапе // Вестник БГУ. Уфа, 2011. Т. 16. №3(I). C. $1052-1054$.

Бакиров М. Х. Генезис и древнейшие формы общетюркской поэзии [Текст] : автореф. дис. ... д-ра филол.наук / М. Х. Бакиров. Казань: КГУ, 1999. 96 с. 
Бурангулов М. А. Завещание Сэсэна [Текст] / Мухаметша Бурангулов; на башк. яз. Уфа: Изд-во «Китап», 1995. 352 с.

Воронцеов M. Народный поэт Башкирии // Народное творчество. 1939. №3 С. 46-48.

Вәлиуллина Ф. М. “Идегәй” дастанында миллимифологик һәм дини мотивлар [Текст] / Ф. М. Валиуллина. Казан: Дом печати, 2007. 180 б.

Газиев И. М. Зарождение профессионализма в музыкальной культуре древних тюрков // Вестник Челябинского государственного педагогического университета. 2008. №12. С.179 - 194.

Жирмунский B.M. Среднеазиатские народные сказители: Традиции и творческая импровизация [Текст] / В. М. Жирмунский. М.: Наука, 1964. 13 с. (VII Международный конгресс антропологических и этнографических наук, Москва, авг. 1964 г.)

Исәнбәт Н. Әсәрләр 4 т. Т.2. Казан: Тат. кит. нәшр., 1988. 416 б.

Исәнбәт Н. Әсәрләр 4 т. Т. 3. Казан: Тат. кит. нәшр., 1988. 431 б.

Идегәй: татар халык дастаны: Н. Исәнбәт жыйнамасы // Совет әдәбияты. 1940. № 11. Б. 39 76 б.

Исәнбәт Н. Татар халык табышмаклары. Казан: Тат. кит. нәшр., 1970. 568 б.

Исәнбәт Н. Бер дәрвишнең юл дәфтәре. // Н. Исәнбәтнең шәхси архивы. Кулъязма. 79 б.

Исәнбәт Н. Минем язучы булуым һәм халык ижатын өйрәнүем. // Н. Исәнбәтнең шәхси архивы. Кулъязма. Машинкада басылган. 1960. 5 б.

Исәнбәт Н. Мыраубай батыр. Казан: Тат. кит. нәшр., 1974. 208 б.

Кашгари М. Словарь тюркских наречий: (Диван лугат-ат тюрк, XI в.) [Текст] / первый перевод на pус. яз. Алматы: Дайк Пресс, 2006. 1300 с.

Путилов Б. Эпическое сказительство: Типология и этническая специфика. М.: ГРВЛ, 1997. 296 с.

Радлов В. В. Опыт словаря тюркских наречий. Т. 4 / [Соч.] В.В. Радлова. СПб.: тип. Имп. акад. наук, 1911. [2] с., 2230 стб.

Татар халык мәкальләре [Текст]: Т. 1. / жыючы һәм төзүче Н. Исәнбәт. Казан: Тат. кит. нәшр., 1959. 916 б.
Сагеева $Г$. Х. Традиционная терминология татарской музыкальной культуры: семантическая реконструкция [Текст]: автореф. дис. ... канд. искусствоведения / Г. Х. Сагеева. Казань: ТГГПУ, 2007. $26 \mathrm{c}$.

Султангареева Р. Башкирская школа сказительства и современность // Ватандаш. Уфа. 2007. №6. С. 164-171.

Сүз табучы сукыр Фәррах әңгәмәләре : [H. Исәнбәтнең «Фәррах жырлары турында» дигән мәкаләсе белән]. Уфа: «Башкнига» һәм Башнаркомпрос нәшере, 1928. 32 б.

Указ Президиума Верховного Совета Башкирской АССР Об установлении звания «Народный сэсэн Башкирской АССР» // Красная Башкирия. 1944. 19 апреля.

Урманче Б. Исәнбәтнең урыны // Казан утлары. 1969. №12. Б. $131-133$.

Урманче $\Phi$. Народный эпос «Идегей». Казан: Фән, 1999. 200 c.

Фәррәх Дәүләтшин // "Башкорт сәсәндәре" йыйынтығында. Өфө: Башк. кит. нәшр., 1953.

Хәбибуллин Ф. Фәррах Дәүләтшин эзләре буйлап // Кызыл Таң. 2017. 19, 21 декабрь.

Хәбибуллин $\Phi$. Алсалар да күземне, бирмәдем мин сүземне... (Башкортстанның халык чәчәне Фәррах Дәүләтшинның тууына 130 ел // Кызыл таң. 2017. 26, 28 гыйнварь.

Хәбибуллин Ф. Сукыр Фәррах // Мәдәни жомга. 2018. 18 май.

Ярми Сәете (Исмәгыйлев). Истәлегем. // Әзәби Башкортостан. 1956. №3, март.

Яруллин А. Память о нём жива (К 120-летию со дня рождения народного поэта Башкортостана) // Юлдаш. 2006. 4 мая.

Йырзар һәм бәйеттер: Орденлы халык йырсыһы Фәррах йырзары һәм бәйеттәре. Өфө: Башк. кит. нәшр.,1939. 112 б.

Сәсәндең кәңәштәре. Өфө: Башк. кит. нәшр, 1947. 63 б.

Сәсән тауышы. Өфө: Башк. кит. нәшр, 1967. 18 б. 


\title{
НАКИ ИСАНБЕТ ОБ ИСКУССТВЕ СКАЗИТЕЛЬСТВА ${ }^{1}$
}

\author{
Милеуша Мухаметзяновна Хабутдинова, \\ Казанский федеральный университет, \\ Россия, 420008, г. Казань, ул. Кремлевская, д. 18, \\ mileuscha@mail.ru.
}

\section{Фануз Афгалович Хабибуллин,} Редакция «Кызыл тан», Россия, 450001, г. Уфа, ул. 50-летия Октября, д. 13, kiziltan90@mail.ru.

\begin{abstract}
В статье систематизируются сведения о вкладе ученого-энциклопедиста, фольклориста, классика татарской литературы Наки Исанбета в осмысление сказительской традиции в тюркской культуре. Материалом для исследования послужили теоретические труды ученого, посвященные изучению фольклора тюркских народов, результаты фольклорных экспедиций, систематизированные в сборниках произведений устного народного творчества, а также художественные произведения писателя, где встречается образ певца-импровизатора. Характер анализируемого текста повлиял на используемый в работе метод исследования (культурноисторический, семиотико-культурологический, сравнительно-сопоставительний и др). Доказано, что Н. Исанбет стремился в своих теоретических трудах по фольклору сформировать исчерпывающее представление о творчестве сэсэнов (чичән) и увековечил их образы в своем литературном творчестве. В 1920 -е гг. экспериментальная работа ученого с Ф. Давлетшиным завершилась изданием сборника его произведений. Анализ современных работ, посвященных феномену сказительства в тюркской среде, свидетельствует о том, что вклад Наки Исанбета в изучение этой темы незаслуженно игнорируется современными исследователями.
\end{abstract}

Ключевые слова: Наки Исанбет, устное народное творчество, тюркские народы, татары, сэсэн (чичән), джырау (жырау).

\footnotetext{
${ }^{1}$ Материал о поэте-импровизаторе Фаррахе Давлетшине подготовлен Ф.А. Хабибуллиным.
} 